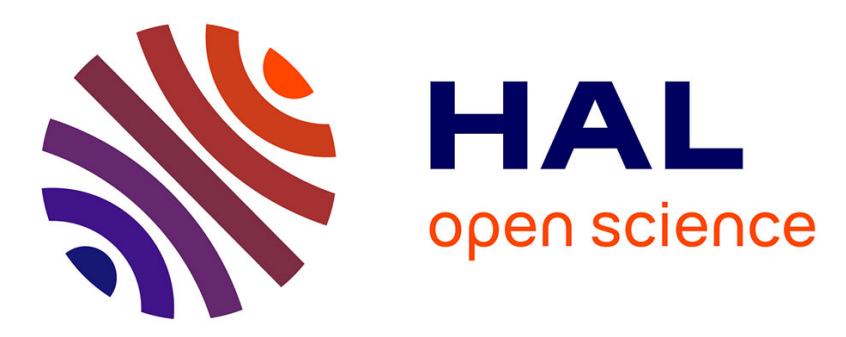

\title{
Basaltic dyke eruptions at Piton de La Fournaise: characterization of the eruptive products with implications for reservoir conditions, conduit processes and eruptive dynamics
}

\author{
Simon Thivet, Lucia Gurioli, Andrea Di Muro
}

\section{To cite this version:}

Simon Thivet, Lucia Gurioli, Andrea Di Muro. Basaltic dyke eruptions at Piton de La Fournaise: characterization of the eruptive products with implications for reservoir conditions, conduit processes and eruptive dynamics. Contributions to Mineralogy and Petrology, 2020, 175 (3), 10.1007/s00410020-1664-5 . hal-02499364

\section{HAL Id: hal-02499364 \\ https://hal.uca.fr/hal-02499364}

Submitted on 5 Mar 2020

HAL is a multi-disciplinary open access archive for the deposit and dissemination of scientific research documents, whether they are published or not. The documents may come from teaching and research institutions in France or abroad, or from public or private research centers.
L'archive ouverte pluridisciplinaire HAL, est destinée au dépôt et à la diffusion de documents scientifiques de niveau recherche, publiés ou non, émanant des établissements d'enseignement et de recherche français ou étrangers, des laboratoires publics ou privés. 
1

Basaltic dyke eruptions at Piton de La Fournaise: characterization of the eruptive products with implications for reservoir conditions, conduit processes and eruptive dynamics

.

Simon Thivet ${ }^{(1)}$, Lucia Gurioli( ${ }^{(1)}$, Andrea Di Muro ${ }^{(2)}$

(1) Laboratoire Magmas et Volcans, Université Clermont Auvergne - CNRS - IRD, OPGC, Campus Universitaire des Cézeaux, 6 Avenue Blaise Pascal, 63178 Aubière Cedex, France

(2) Institut de Physique du Globe (IPGP), Sorbonne Paris-Cité, CNRS UMR-7154, Université Paris Diderot, Observatoire Volcanologique du Piton de la Fournaise (OVPF), Bourg Murat, France

Author contact: simon.thivet@uca.fr (Orcid: 0000-0003-0836-6421)

\section{Acknowledgments}

We thank A. J. L. Harris and G. Boudoire for the syn-eruptive sampling of the July 2015 products, J-L. Devidal and J-M. Hénot for their precious support in using the electronic microprobe and the SEM, and M. Benbakkar for the bulk rock analysis. We thank M.D. Higgins and L. Pioli with whom we had constructive discussions. This paper was greatly improved by the critical review of the anonymous reviewer and the editor. We thank the STRAP project funded by the Agence Nationale de la Recherche (ANR-14-CE03-0004-04). This research was financed by the French Government Laboratory of Excellence initiative no. ANR-10-LABX-0006, the Région Auvergne and the European Regional Development Fund. This is Laboratory of Excellence Clervolc contribution number 401. 

la Fournaise (La Reunion Island, France). Their eruptive style ranges from Hawaiian to Strombolian but their eruptive mechanisms are still not completely understood. To gain insight, we combined syn-eruptive field work, textural and geochemical measurements on the short-lived eruption of July 2015 and we compared it with the 2014 eruption, which opened the ongoing eruptive cycle at Piton de la Fournaise. Crystal-poor and moderately vesicular components were predominant at the beginning of the eruptions, during the lava flux peak and the Hawaiian-style activity. Their abundance decreased with time in favour of less vesiculated and crystal-rich components during the decrease of the lava flux and the Strombolian-style activity. Physical, textural and chemical characterization of the pyroclasts, as well as thermometry calculations, permit to relate the different texture and chemical features of the eruptive products with the pre- and syn-eruptive processes. Geophysical precursors detected several weeks before the July 2015 eruption, as well as some evidences of magmatic reheating recorded in bulk and crystal compositions highlight that the July 2015 magma results from a pre-eruptive mixing between more and less differentiated magmas. We finally deduced that the observed syn-eruptive textural variations are related to the same batch of magma undergoing different cooling and degassing dynamics. 


\subsection{Context}

Basaltic systems exhibit a wide range of magmatic eruption styles, from effusive eruptions generating lava flows (e.g. Harris et al. 2007, 2017; Staudacher et al. 2016), Hawaiian and/or Strombolian-style activities (e.g. Head and Wilson et al. 1987, 1989; Jaupart and Vergniolle 1988, 1989; Parfitt and Wilson 1995; Parfitt, 2004; Stovall et al. 2011, 2012; Houghton et al. 2016), up to more violent explosions (e.g. Houghton and Gonnermann 2008; Morandi et al. 2016; Ort et al. 2016). Eruptive styles are controlled primarily by syn-eruptive magma ascent dynamics within volcanic conduit systems (e.g. Sparks 1978; Vergniolle and Jaupart 1990; Houghton et al. 2004; Gonnermann and Manga 2013; Applegarth et al. 2013; Pioli et al. 2012, 2017; Pering et al. 2017) and pre-eruptive magmatic conditions of the reservoirs (e.g. Sparks and Huppert 1984; Anderson 1995; Corsaro and Pompilio 2004; Roeder et al. 2006; Gurioli et al. 2018). These dynamics are strongly dependent on the physicochemical properties of the magma, like its temperature, pressure, volatiles content and chemical composition (e.g. Tait et al. 1989; Di Muro et al. 2014, 2015, 2016; La Spina et al. 2015; Mollo et al. 2015; Rae et al. 2016).

Petrographic and textural measurements on basaltic products can provide critical information regarding the pre-eruptive storage and magma ascent conditions (e.g. Kuo and Kirkpatrick 1982; Polacci et al. 2006, 2012; Di Muro et al. 2014, 2015 ; Pioli et al. 2014; Gurioli et al. 2015, 2018). However, post-fragmentation effects can obliterate the primary signature of the magma, especially during high intensity lava fountain activities (e.g. Mangan and Cashman 1996; Stovall et al. 2011, 2012; Parcheta et al. 2013; Moitra et al. 2013, 2018; Kawabata et al. 2015; Lindoo et al. 2016, 2017). Piton de la Fournaise (PdF) is one of the most active volcanoes in the world in term of eruption frequency but it frequently exhibits low intensity Hawaiian to Strombolian-style activities, allowing efficient and fast natural quenching of the eruptive products that are not significantly modified by postfragmentation expansion phenomena. Recently, Gurioli et al. (2018) have shown that the textural features of the pyroclast products from the mild recent activity of PdF are representative of the fragmentation conditions and thus can provide information related to (i) the shallow reservoirs which feed the eruptions and (ii) track the degassing history of the ascending magmas. These latter authors also provided a complete dataset of the June 2014 eruption that marked the beginning of a new and still ongoing eruptive cycle at PdF after a long quiescence period.

\subsection{Objectives}



focused on (i) the eruption triggering and the general processes driving a magmatic system reactivation as well as on (ii) the mechanisms controlling the eruptive styles. More specifically, we wanted to check if the processes operating at the origin of the magmatic overpressures triggering such eruptions were different on the entire period of June 2014-July 2015, and if the textural signature of the emitted products reveal similar or different ascent dynamics and degassing histories in the eruptive dyke.

In this work, we combine macroscopic analysis (componentry), bulk texture measurements (density, porosity and vesicle connectivity), microscopic texture measurements (Vesicle Size Distribution, VSD and Crystal Size Distribution, CSD), and petro-chemical analysis (bulk rock, glass and crystal compositions) on lava and tephra, of the July 2015 eruption at PdF. We also completed the textural dataset of Gurioli et al. (2018), adding the CSD of the June 2014 eruptive products. In parallel, these data are integrated with componentry measurements acquired on the June 2014, February and May 2015 eruptions of PdF, also with already published bulk rock analyses, experimental data (cooling experiments) and geophysical insights acquired on the June 2014-July 2015 period (ground deformations, magma output rates and seismic spectrograms). All these types of data are also important to characterize as they can be eventually compared to the output of physics-based models in order to better constrain physical parameters related to magma storage and conduit processes.

\section{Geological background}

\subsection{The shallow magma storage system of PdF}

With the exception of three eruptions that occurred during the twentieth century, the recent volcanic activity of PdF is confined within the Enclos Fouqué caldera which corresponds to the most recent big caldera of the volcano (Bachèlery 1981). This caldera is a poly-lobed depression, 100 to $250 \mathrm{~m}$ depth, in the centre of which the cone of PdF is built (Fig. 1a). According to the seismic data acquired by the Observatoire Volcanologique du Piton de La Fournaise (OVPF) monitored by the Institut de Physique du Globe de Paris (IPGP), the magmatic system feeding the central activity at PdF, extends vertically in the crust between the volcano top ( $2.6 \mathrm{~km}$ above the sea level) and $7 \mathrm{~km}$ below the sea level (Battaglia et al. 2005; Peltier et al. 2015; Lengliné et al. 2016). Geophysical data suggest that the main shallow magmatic storage system is located close to the sea level below the central cone (Peltier et al. 2008; Prôno et al. 2009). Based on surface deformations, Peltier et al. (2008) 
interpreted the summit or proximal eruptions (located close to the central cone of PdF), with low volume and short time lag between initiation of the dyke propagation and the beginning of the eruption, as the drain of small and shallow (above sea level) volumes located beneath the volcano summit. Geochemical and barometric data (Di Muro et al. 2014, 2015) as well as geodetic data (Peltier et al. 2016) support the existence of a multitude of shallow crustal reservoirs, which represent an active storage unit below the central cone.

\subsection{The 2014-2015 eruptions: the beginning of a new eruptive cycle}

Recent activity at PdF produces on average one eruption every nine months (Roult et al. 2012) but cycles of frequent eruptive activity alternate with phases of quiescence lasting up to six years (Peltier et al. 2008). The April 2007 major caldera-forming eruption represents one of the most intense and voluminous events of the historical activity of PdF (Staudacher et al. 2009). This large eruption was followed by a set of small-volume eruptions and shallow intrusions between 2008 and 2011, followed by a 41 months long resting phase, between 2011 and 2014 (Fig. 1b; Peltier et al. 2016). Sudden and quite weak precursors of new unrest were detected in June 2014: after 11 days of weak inflation, a new short-lived eruption started the 20 June 2014 (Gurioli et al. 2018). This event marked the beginning of a new, and still ongoing, cycle of activity at PdF that produced five eruptions in the 2014-2015 period.

With the remarkable exception of the complex, long lasting and large August-October 2015 event (emitted volume of $45.210^{6} \mathrm{~m}^{3}$; Coppola et al. 2017), the eruptions of the 2014-2015 period had relatively simple patterns of rapid exponential decay in magma output rates or TADR (time-averaged lava discharge rates; Harris et al. 2007) and emplaced relatively small volumes of lava (all $<1010^{6} \mathrm{~m}^{3}$ and often $<210^{6} \mathrm{~m}^{3}$ ). Indeed, the first four eruptions of the 2014-2015 period, share relatively similar characteristics in terms of duration, eruption pattern and total extruded volume $\left(0.310^{6} \pm 0.1\right.$ for June 2014, $0.810^{6} \pm 0.3$ for February 2015, $6.510^{6} \pm 2.3$ for May 2015 and 1.6 $10^{6} \pm 0.6 \mathrm{~m}^{3}$ for July 2015; Coppola et al. 2017).

Bulk rock composition changed during the 2014-2015 eruptions, suggesting initial differentiation followed by a progressive mixing of the resident, evolved magma with a primitive magma batch, whose volumetric contribution further increased during the large August 2015 eruption (Coppola et al. 2017). The 2014-2015 set of eruptions has thus been interpreted as the result of a major phase of refilling and rejuvenation of the shallow PdF plumbing system, which had been substantially drained away in the caldera forming 2007 eruption (Di Muro et al. 2014; Peltier et al. 2016). The June 2014 (evolved magma) and the July 2015 (hybrid magma) events are the focus of this research. 


\subsection{Chronology and field sampling of the July 2015 eruption}

Since mid-April 2015, several precursors were observed (Peltier et al. 2016): deep seismicity was detected below the central cone, associated with a change in the composition of the intra-caldera gas emissions $\left(\mathrm{CO}_{2}\right.$ and $\mathrm{H}_{2} \mathrm{~S}$ enrichment in the summit fumaroles) and an increase of the summit ground inflation ( $4 \mathrm{~cm}$ along the summit GNSS baseline, three months before the eruption; Fig. 1b). According to the OVPF activity bulletin of July 2015 (ISSN 2610-5101; http://www.ipgp.fr/fr/ovpf/bulletin-dactivite-mois-de-juillet-2015), the July 2015 eruption started on the 31 July at 5:20 a.m. (all time cited in this paper are in UTC) after an intensification in the shallow volcano-tectonic (VT) seismicity located below the volcano central cone (seismicity peaks on the 7, 13, 28 and 31 of July). This eruption was thus preceded by a set of unambiguous precursors and a longer lasting phase of preeruptive inflation with respect to the smaller and sudden inflation recorded only 11 days before the June 2014 eruption (Gurioli et al. 2018) as well as relatively weak inflation preceding the February and May 2015 eruptions (Peltier et al. 2016; Fig. 1b).

Following the OVPF activity bulletins and field observations, the July 2015 eruption occurred along two en-echelon eruptive fissures (upper and lower fissures), corresponding to the same dyke, which extended from the NE of the 1998 Piton Kapor cone towards the NNE (Fig. 1a). This eruption was located in the N10 rift zone defined by Bachèlery (1981). Lava fountains at the beginning of the eruption were followed by mild Strombolian explosions towards the end of the eruption, which formed a set of aligned pyroclastic cones and fed several lava flows (Fig. 2), some of them spreading out to the North of the Grandes Pentes area (Fig. 1a). On the basis of the thermal emission measured by the MODIS sensor (Moderate Resolution Imaging Spectroradiometer, MIROVA monitoring system, Coppola et al. 2016), the maximum TADR was estimated at $22 \pm 8 \mathrm{~m}^{3} \mathrm{~s}^{-1}$ during the first hours of the eruption and then declined exponentially towards the end of the eruptive activity. In comparison, the TADR of the June 2014 eruption followed a comparable temporal trend but its maximum output rate was three times lower than that of July 2015. From the night between the 31 July and 1 August, the tremor intensity and TADR started to decrease, mirroring a rapid decline in the magmatic activity and the closure of some eruptive vents. After several hours of intensity seismic fluctuation, corresponding to gas piston events, the tremor disappeared the 2 August at around 7:30 am after 50 hours of activity.

The two eruptive fissures did not produce the same activity during the eruption. (i) The upper fissure was active all along the eruption and the main part of the activity was concentrated in this area, especially in the northernmost cone (which grew progressively during the eruption and is described as the main cone of the eruption, 
Figs. 1a and 2) of this eruptive fissure. (ii) The lower fissure (towards the NNE; Figs. 1a, 2a and 2d) began to form few hours after the upper one, during the maximum TADR and its activity stopped about one or two hours before that of the upper fissure. Nevertheless, the transition between Hawaiian and Strombolian-style activity observed during the eruption was widespread and happened quite suddenly at the same time along both fissures (Fig. 2).

Thanks to the rapid scientific response of the OVPF and the DynVolc teams (Harris et al. 2017), as well as relatively good weather conditions, detailed syn-eruptive sampling and characterisation of eruptive dynamics were performed. The juvenile samples were collected close to different active zones and at different times to constrain the eruptive dynamics both in space and time (Fig. 1b and Table S1). The first sampling site was the main cone of the eruption, at the NNE extremity of the upper fissure (Figs. 1b and 2). The sampling of this site was done a few hours after the beginning of the eruption, when Hawaiian fountaining was still intense and during the maximum TADR phase. The second sampling site was the other part of the upper fissure, which was active throughout the entire eruption. Sampling was done during the second part of the eruption and the mild Strombolianstyle activity, when TADR was declining. Finally, the third and last sampling site was the lower fissure, which opened just after the upper one and its sampling was performed during the second part of the eruption as well. These three sampling sites permitted to document the change in eruptive style and the decline in eruption intensity (from Hawaiian to Strombolian-styles). Lava samples were directly taken from the active lava flows (mainly the one emitted from the main cone) and gently quenched in water. It is important to note that most of the lava samples were sampled in the same way and near their point of emission (Harris et al. 2017). Hereafter these lava samples will be called typical lava sample.

\section{Laboratory Methods}

After the eruption, all the samples were brought to the Laboratoire Magmas et Volcans (LMV) at Clermont-Ferrand, France, to be analysed and then stored at the OVPF and LMV repositories. A full description of the routine measurements reported below, as well as the raw data presented in this paper, are available in the DynVolc database (2017) and the supplementary material of this paper.

\subsection{Componentry}

Considering that each sampling was done randomly (with no clasts selection), the samples are representative of the type of the activity at that moment, without any sample biasing. Specimen selection can be 
done afterwards in the laboratory. Following the nomenclature of White and Houghton (2006) clasts were subdivided into three broad components: juvenile, non-juvenile and composite fragments. Based on the Gurioli et al. (2018) nomenclature, juvenile fragments are then classified based on their macroscopic characteristics (surface typology, shape and colour).

\subsection{Bulk texture}

Density and Helium (He) vesicle connectivity measurements were performed on 208 samples (lapilli, bombs and lava fragments). Two different methods were used for these density measurements (Table S2). (i) First, the density was measured using the water-immersion technique based on the Archimedes principle described by Houghton and Wilson (1989) and Shea et al. (2010). This technique is the most used, and allows us to compare a wide range of data with a good reproducibility of $\pm 40 \mathrm{~kg} \mathrm{~m}^{-3}(1 \sigma)$ on five repeated measurements. (ii) Another method was performed using a density analyser (Micromeritics Geopyc 1360, Fig S1). As already briefly presented by Kawabata et al. (2015), the instrument measures object volume and density of particles with different sizes and shapes. These density measurements lead to reproducible data with a maximum standard deviation of $\pm 30 \mathrm{~kg} \mathrm{~m}^{-3}$ $(1 \sigma)$ on five repeated measurements. For the sake of accuracy, several samples were analysed using the two methods described above and the data correlate relatively well (Table S2). Moreover, the errors of these measurements are insignificant in comparison with the variability of natural porosity in the samples (Gurioli et al. 2015). The porosity of the samples was then calculated based on Houghton and Wilson (1989) using a vesicle-free rock density of $2884 \pm 35 \mathrm{~kg} \mathrm{~m}^{-3}(1 \sigma)$. This parameter was determined by powdering four samples and by measuring their masses and volumes using the Micromeritics Accupyc 1340 Helium pycnometer (maximum standard deviation of $\pm 3.10^{-8} \mathrm{~m}^{3}, 1 \sigma$, on five repeated measurements for the volume measurements). The Accupyc pycnometer was also used to determine the skeletal volumes of the samples in order to calculate the He vesicle connectivity for each clast (Table S2), using the Formenti and Druitt (2003) and Colombier et al. (2017) methods.

\subsection{Microscopic texture}

Based on the density distribution and the variability of the clasts, seven pyroclasts and four lava samples, covering the texture evolution in time and space of the July 2015 eruption, have been selected (Table S3). In order to perform a detailed comparison with the products of the June 2014 eruption, we extended the original dataset of Gurioli et al. (2018) by adding the CSD data of eight samples (seven pyroclasts and one lava fragment) of that eruption. Multiple magnification images were taken in order to quantify all the petrographic characteristics of both pyroclasts and lava samples from the micron (25x and 100x magnifications realized with the JEOL JSM-5910 LV 
Scanning Electron Microscope (SEM) and using Back-Scattered Electron (BSE) images with an acceleration voltage of $15 \mathrm{kV}$ ) to the centimetre scales (thin section scans both under natural and polarized light).

All these images were then transformed and binarized in grayscale to allow Matlab program FOAMS (version 1.0.5; Shea et al. 2010) to acquire 2D raw data of all the selected objects (vesicles and crystals) and calculate 3D textural characteristics of the samples, based on the whole sets of images. Both for vesicles and crystals, the minimum object measured was five pixels (equivalent to $6 \mu \mathrm{m}$ at the maximum magnification 100x we used with the SEM). VSD and vesicle number density $\left(\mathrm{N}_{\mathrm{V}}\right)$ were measured with FOAMS (Shea et al. 2010) counting a total of 48528 vesicles measured for both the July 2015 and June 2014 eruptions. Vesicle to melt ratio $\left(\mathrm{V}_{\mathrm{G}} / \mathrm{V}_{\mathrm{L}}\right)$ was calculated following Gardner et al. (1996). This ratio represent the vesicle volume divided by the matrix volume. $\mathrm{N}_{\mathrm{V}}$ and $\mathrm{V}_{\mathrm{G}} / \mathrm{V}_{\mathrm{L}}$ parameters are corrected for the phenocryst content.

Based on 2D measurements of several thousands of crystals, 3D crystal habits (x:y:z) were determined using CSDslice database (version 4; Morgan and Jerram, 2006): the best fit dimensions are 1:4:10 (tabular shape) for plagioclase crystals and 1:1.5:2.4 (rectangular prism shape) for clinopyroxene crystals. Then CSDcorrections software (version 1.6; Higgins 2000) was used to calculate the CSD, crystal content and crystal number density $\left(\mathrm{N}_{\mathrm{C}}\right)$ of the samples. Based on SEM image observations, the circularity of the crystals is fixed at 0.1 and 0.3 for plagioclase and clinopyroxene, respectively (on a scale of 0 to 1 ). Olivines and oxides are too rare in the eruptive products of 2014 and 2015 to be statistically measured. As the raw data of crystals from FOAMS are obtained from several nested image magnifications, normalized size frequency data from FOAMS is the most appropriate input to use within the CSDcorrections software. This frequency data calculated from FOAMS $\left(\mathrm{N}_{\mathrm{A}}\right.$, number per unit of area) were used in the frequency data input section of the CSDcorrections software. Calculations are corrected for the vesicle content. Moreover, FOAMS size frequency raw data are based on the crystal equivalent diameters, whereas CSDcorrections input does not use this shape parameter. Thus, the best input measurement to use is the major axis of the crystal ellipse combined with the phase abundance correction measured with FOAMS and corrected for the porosity. This procedure is a requirement to correct stereological conversion of 2D crystal size measurement to 3D CSDs by combining the FOAMS program output with the CSDcorrections software. Based on the work of Cashman (1988), Marsh (1988) and Higgins (2006), one CSD slope theoretically defines a specific crystal population, which form during a single step of nucleation and growth. Slope changes permit to identify different crystal populations (the steeper the slope, the lower the residence time assuming a constant growth, or inversely the steeper the slope, the lower the growth rate assuming a constant residence time). In our dataset, the slope change was defined by the intercept of the best fitting lines of the different crystal populations. 
All the textural parameters described in this section, as well as the crystal nucleation density $\left(\mathrm{N}^{0}\right)$, which is the CSD value at $\mathrm{x}$ (crystal length) $=0$, are reported in the Table S3

\subsection{Chemical analysis}

Bulk rock analyses (ICP-AES) discussed in this study have been already published (Coppola et al. 2017; Gurioli et al. 2018) and were performed on several quenched pyroclasts and lavas (Table S4). We compare these data with our new micro-analyses of July 2015 glasses and crystals (Table S4). They were carried out for major elements by using the Cameca SX100 Electron Probe Micro-Analyser (EPMA). EPMA analysis of June 2014 products have been already published in Gurioli et al. (2018). Counting times were 10 seconds for each element, with an acceleration voltage of $15 \mathrm{kV}$ and a current intensity of $8 \mathrm{nA}$. A $10 \mu \mathrm{m}$ beam and a focused beam were used for the glass and crystal analysis respectively. Maximum errors $(2 \sigma ; \mathrm{wt} \%)$ for each oxides are \pm 0.87 for $\mathrm{SiO}_{2}$, \pm 0.15 for $\mathrm{TiO}_{2}, \pm 0.36$ for $\mathrm{Al}_{2} \mathrm{O}_{3}, \pm 0.67$ for $\mathrm{FeO}, \pm 0.17$ for $\mathrm{MnO}, \pm 0.37$ for $\mathrm{MgO}, \pm 0.32$ for $\mathrm{CaO}, \pm 0.31$ for $\mathrm{Na}_{2} \mathrm{O}, \pm 0.04$ for $\mathrm{K}_{2} \mathrm{O}$ and \pm 0.16 for $\mathrm{P}_{2} \mathrm{O}_{5}$.

We also estimated the equilibrium of each mineral phase with bulk rock and glass compositions (Table S4). For the plagioclase (plg), we used the plagioclase/liquid equilibrium constant of Putirka (2008) calibrated for melts whose temperature exceeds $1050^{\circ} \mathrm{C}: \mathrm{K}_{\mathrm{D}}(\mathrm{An}-\mathrm{Ab})=\left(\mathrm{X}_{\mathrm{Ab}}^{\mathrm{plg}} \mathrm{X}_{\mathrm{AlO}_{1.5}}^{\mathrm{liq}} \mathrm{X}_{\mathrm{CaO}}^{\mathrm{liq}}\right) /\left(\mathrm{X}_{\mathrm{An}}^{\mathrm{plg}} \mathrm{X}_{\mathrm{NaO}_{0.5}}^{\mathrm{liq}} \mathrm{X}_{\mathrm{SiO}_{2}}^{\mathrm{liq}}\right)=0.27 \pm$ 0.11 , where $\mathrm{X}$ is the molar fraction of the corresponding oxides or albite/anorthite content within plg and melt. For the clinopyroxene (cpx), we used the $\mathrm{Mg}-\mathrm{Fe}$ coefficient distribution $\mathrm{K}_{\mathrm{D}}(\mathrm{Mg}-\mathrm{Fe})=\left(\mathrm{X}_{\mathrm{FeO}}^{\mathrm{cpx}} \mathrm{X}_{\mathrm{MgO}}^{\mathrm{liq}}\right) /$ $\left(\mathrm{X}_{\mathrm{FeO}}^{\mathrm{liq}} \mathrm{X}_{\mathrm{MgO}}^{\mathrm{cpx}}\right)=0.28 \pm 0.05$ at equilibrium (Putirka 2008; Brugier 2016). Similarly for the olivines, we used the $\mathrm{Mg}-\mathrm{Fe}$ distribution coefficient $\mathrm{K}_{\mathrm{D}}(\mathrm{Mg}-\mathrm{Fe})=\left(\mathrm{X}_{\mathrm{FeO}}^{\mathrm{ol}} \mathrm{X}_{\mathrm{MgO}}^{\mathrm{liq}}\right) /\left(\mathrm{X}_{\mathrm{FeO}}^{\mathrm{liq}} \mathrm{X}_{\mathrm{MgO}}^{\mathrm{ol}}\right)$ from Roeder and Emslie $\left(1970 ; \mathrm{K}_{\mathrm{D}}=\right.$ 0.30 at equilibrium), Fisk et al. $\left(1988 ; \mathrm{K}_{\mathrm{D}}=0.306\right.$ at equilibrium) and Putirka $\left(2008 ; \mathrm{K}_{\mathrm{D}}=0.30 \pm 0.03\right.$ at equilibrium). An average $\mathrm{Fe}^{3+} / \mathrm{Fe}_{\text {total }}$ ratio of 0.18 , calibrated for La Réunion Island basaltic melts (Pichavant et al. 2016), was used to calculate $\mathrm{FeO}$ content of the liquid phase.

\subsection{Geothermometry setup and $\mathrm{H}_{2} \mathrm{O}$ content estimations}

Recently, Brugier (2016) studied experimentally the evolution of phase equilibria and phase compositions during the cooling of November 2009 mafic magma in the temperature range 1200-1100 ${ }^{\circ} \mathrm{C}$. Two sets of experiments were performed (i) at $50 \mathrm{MPa}$ with 0.5 to 1.6 dissolved $\mathrm{H}_{2} \mathrm{O}$ content in the melt, that is at the $\mathrm{H}_{2} \mathrm{O}$ $\mathrm{CO}_{2}$ saturation pressure typically recorded by olivine hosted melt inclusions at PdF (Di Muro et al. 2014, 2016), 
and (ii) at atmospheric and dry conditions. (i) Hydrous experimental data of Brugier (2016) acquired at $50 \mathrm{MPa}$ and controlled redox conditions (between NNO and NNO-1.7) are fitted to define a first hydrous $\mathrm{MgO}-$ thermometer (black line in Fig. S2): $T\left({ }^{\circ} \mathrm{C}\right)=943.7+27.5 \mathrm{MgO}^{\text {liq }}\left(\mathrm{R}^{2}=0.83\right)$. (ii) Experimental data of Brugier (2016) acquired at atmospheric and controlled redox conditions (NNO and NNO-0.5) are fitted to define a second MgO-thermometer for sub-surface dry magmatic conditions (blue line in Fig. S2): $T\left({ }^{\circ} C\right)=1041.7+$ 17.7 $\mathrm{MgO}^{\text {liq }}\left(\mathrm{R}^{2}=0.75\right)$. Then we are able to compare these newly calibrated thermometers with already published ones (Fig. S2).

$\mathrm{H}_{2} \mathrm{O}$ content within the natural melts of July 2015 eruption are also estimated using the plagioclase-melt hygrometer of Lange et al. (2009).

\section{Results}

\subsection{Componentry}

The July 2015 products consist of juvenile fractions which represent the primary magma involved in these eruptions (lavas and pyroclasts). Based on the classification of Gurioli et al. (2018), the July 2015 tephra samples were divided into four types of juvenile pyroclasts: (i) golden pumice, (ii) fluidal scoria, (iii) spiny-glassy scoria and (iv) spiny-opaque scoria. As described by these latter authors, golden pumice are characterized by very smooth, shiny and brown/yellow surfaces. Fluidal scoria are characterized by smooth and shiny dark surfaces. Spiny-glassy scoria show shiny but rough and spiny surfaces. Spiny-opaque clasts are characterized by dark matt and spiny surfaces.

Figure 3 represents the componentry measurements performed on the first four eruptions of the 20142015 period, as well as their associated TADR (Coppola et al. 2017). The time distribution of the different eruptive components is not constant in time and evolved in parallel with changes in TADR. Samples of the initial phase of these four eruptions show that the pyroclasts emitted during this initial intense phase were mostly fluidal clasts.

Only one golden pumice was collected during the initial intense phase of the July 2015 eruption. The scarcity in golden pumice during the three eruptions occurring in 2015 contrasts with the June 2014 eruption, which emitted a significant amount of golden pumice during the maximum TADR (Fig. 3a). Additionally, samples collected in the declining phases of these four eruptions (with relatively low TADR and mild Strombolian-style activity) mostly consist of spiny scoria (both spiny-glassy and spiny-opaque). 


\subsection{Bulk texture}

The textural components are marked by distinct porosity distributions and textures (Fig. 4a). Focusing on the July 2015 dataset, the porosities of the spiny clasts (both glassy and opaque) vary from 34 to $75 \mathrm{vol} \%$ with an average of $54 \mathrm{vol} \%$, while the porosities of the fluidal clasts vary from 44 to $82 \mathrm{vol} \%$ with an average of $72 \mathrm{vol} \%$. Only one golden pumice sample has a porosity of $79 \mathrm{vol} \%$. The magma emitted during the maximum TADR is quite porous, while the magma erupted during the decrease in TADR is denser. Typical lava fragments sampled close to the main vent have a density range between 44 and 58 vol\% close to that of spiny clasts. However, two lava fragments sampled within the channel, around $100 \mathrm{~m}$ from the emission point record extreme density values ( $82 \mathrm{vol} \%$ for the vesicle-rich lava sample and $27 \mathrm{vol} \%$ for the dense one). The dense fragment was collected from the channel margin, while the vesicle-rich one was collected within the channel plug, therefore not representative any more of the vent conditions (Harris et al. 2019).

Vesicle He connectivity measurements (Fig. 4b) show that the content in isolated vesicles increases in porous clasts with bulk porosity > $60 \mathrm{vol} \%$. The July 2015 fluidal clasts and golden pumice have variable content of isolated vesicles up to $40 \mathrm{vol} \%$. In contrast, spiny clasts and lavas have less or no isolated vesicles (from 0 to $15 \mathrm{vol} \%)$.

\subsection{Micro texture}

Figure 5 represents an overview of the textures of the different pyroclasts and lavas from July 2015 eruption. General and qualitative information are provided here, being quantitatively detailed in the sections hereafter. (i) Golden pumice clasts (Fig. 5a) are highly porous and crystal-poor. Thin sections and SEM images show a very low micro-crystallinity, and micro-phenocrysts (called mesocrysts by Gurioli et al. 2018) are very scarce in these samples. Vesicles are rounded. (ii) Fluidal scoria samples (Fig. 5b) have variable but still high porosities and contain slightly more microlites than the golden clasts, and scarce micro-phenocrysts. Vesicles are rounded. (iii) Spiny-glassy scoria (Fig. 5c) have lower porosities than the two previous components and a few big irregular coalesced vesicles occur. Microlites are more abundant and larger, and micro-phenocrysts are still scarce. (iv) Spiny-opaque scoria (Fig. 5d) porosities are quite similar or even lower than in the spiny-glassy scoria with several big coalesced vesicles. Their crystal contents are clearly higher than in the other types of pyroclasts, but still with low micro-phenocryst contents. (v) Typical lavas (Fig. 5e) are dense with intermediate crystal content and show a similar micro-phenocrysts content as in the pyroclasts. The lavas sampled down the flow (not shown in Fig. 5), namely the dense one from the lava flow edges (shear-zone) and the vesicle-rich one from the lava flow 
center (plug), have extreme values of porosities and the dense lava contains a larger amount of microlites than the vesicle-rich lava (Harris et al. 2019).

\subsubsection{Vesicle characteristics and size distributions}

Figure 6a shows the VSD as a function of the total volume that the vesicles represent in the measured samples. The 2015 golden pumice VSD shows a single population of vesicles, ranging from $20 \mu \mathrm{m}$ to $2.5 \mathrm{~mm}$ in diameter, with vesicles of $0.4 \mathrm{~mm}$ representing the main mode. A similar distribution is found in the four fluidal scoria pyroclasts that contain also a few big rounded vesicles, up to $4 \mathrm{~mm}$ in diameter. Both VSDs of spiny-glassy and spiny-opaque scoria show a bimodal distribution. The main population of this latter distribution corresponds to small vesicles whose main size mode coincides approximately with that of the previous clast types $(0.4$ and 0.2 $\mathrm{mm}$ for the spiny-glassy and spiny-opaque samples respectively). However, the volume of this population is about half than the one found in the fluidal and golden clasts. The second population corresponds to large vesicles with irregular contours whose size ranges between 1.5 and $6 \mathrm{~mm}$ in diameter. The VSDs of lavas have asymmetric distribution with a main mode of large vesicles at $1 \mathrm{~mm}$ in diameter and isolated peaks of large vesicles up to 6 $\mathrm{mm}$. The VSD of the dense lava sample has an asymmetric distribution skewed toward large vesicles and a very low total vesicle volume fraction. In contrast, the VSD of the vesicle-rich lava sample is characterized by a unimodal population of small vesicles with a mode at $0.6 \mathrm{~mm}$.

Both vesicle number density and vesicle to melt ratios progressively decrease from the golden and fluidal clasts to the spiny clasts and lavas, except the vesicle-rich lava (Fig. $6 \mathrm{~b}$ ). $\mathrm{V}_{\mathrm{G}} / \mathrm{V}_{\mathrm{L}}$ of the 2015 dataset decrease from the golden pumice (4.6), to the fluidal scoria (between 1.5 and 4.4) and to the spiny scoria (1.2). The $\mathrm{V}_{\mathrm{G}} / \mathrm{V}_{\mathrm{L}}$ ratio of typical lavas are closed to 1, with the exception of the vesicle-rich (4.9) and dense (0.4) fragments. July 2015 $\mathrm{N}_{\mathrm{V}}$ values decrease from golden pumice and fluidal scoria (between $2.610^{2}$ and $1.510^{3} \mathrm{~mm}^{-3}$ ) to spiny scoria (between $1.710^{2}$ and $4.110^{2} \mathrm{~mm}^{-3}$ ). $\mathrm{N}_{\mathrm{V}}$ for lava samples are lower than $2.210^{2} \mathrm{~mm}^{-3}$.

\subsubsection{Mineral assemblage and Crystal Size Distributions}

The July 2015 pyroclasts and lavas contain plagioclase (plg), clinopyroxene (cpx) and scarce olivine (ol) in order of decreasing abundance and size (Fig. 5). Micro-phenocrysts occur as isolated or clusters of several euhedral crystals of plg, cpx and scarce ol. Little resorption/dissolution textures are observed within the 2015 micro-phenocrysts of ol (cf. 100x BSE image of the typical lava sample on Fig. 5e). Evidences of crystal resorption have not been found in the other phases (plg and cpx) of the July 2015 magma. Microlite texture is similar for both 
eruptions, with both isolated and aggregated crystals. Aggregates consists of plg microlites crosscuting cpx grains. $\mathrm{Ol}$ is scarce and isolated.

The limit between the microlite and micro-phenocryst populations on plg and cpx (Fig. 7a) is mostly dependent on the maximum length of the microlite population that evolves from a component to another. Ol crystals, smaller in size than plg and cpx, were too scarce for statistical analysis. The maximum length of the 2015 plg microlites (equivalent to the 3D crystal length) increases from golden pumice $(0.5 \mathrm{~mm})$ to fluidal and spinyglassy scoria $(0.9 \mathrm{~mm})$ to lava $(1.1 \mathrm{~mm})$ and spiny-opaque scoria $(1.2 \mathrm{~mm})$; the maximum length of the cpx microlites increase from golden pumice $(0.1 \mathrm{~mm})$ to spiny-glassy scoria $(0.4 \mathrm{~mm})$ to lava $(0.6 \mathrm{~mm})$ and fluidal and spiny-opaque $(0.7 \mathrm{~mm})$. We also performed CSD analysis on some June 2014 eruptive products, that was not presented in Gurioli et al. (2018) and the maximum length evolution of the June 2014 microlites also show the same trend.

July 2015 crystal content varies significantly in the different components (Fig. 7b), while their CSDs change only little (Fig. 7a). (i) In the golden pumice, few microlites formed mostly by plg (10 vol\%) and scarce cpx ( $1 \mathrm{vol} \%)$ were observed (plg/cpx microlites volume ratio of 10$)$. Total crystal content of golden pumice is the lowest of all the components with only 11 vol\% of microlites with very scarce micro-phenocrysts ( $<1$ vol\%). (ii) Fluidal scoria contain a slightly higher content of microlites (13 to $18 \mathrm{vol} \%$ with an average plg/cpx of 5) and their content in micro-phenocrysts remain very low (around 1 vol\%). (iii) Spiny-glassy and spiny-opaque have higher content in microlites (25 and $43 \mathrm{vol} \%$ respectively with an average plg/cpx of 3 ) and micro-phenocrysts are slightly more abundant (4 and 5 vol\% respectively). (iv) Microlite content from typical lava fragments (excluding the vesicle-rich and dense one) range from 28 to $34 \mathrm{vol} \%$ (average plg/cpx of 3) with 1 to $3 \mathrm{vol} \%$ of micro-phenocrysts. Maximum size of micro-phenocrysts is the same for all the components (no more than $4 \mathrm{~mm}$ ), except for the golden pumice in which big crystals are not incorporated. CSD of the June 2014 products show that these products incorporated bigger micro-phenocrysts of plg and cpx (up to $8 \mathrm{~mm}$ ) than the July 2015 magma.

\subsection{Bulk rock, glass, crystals and experimental analyses}

\subsubsection{Crystal compositions}

We identified three different groups of crystals with distinct compositions and sizes: (i) the phenocrysts, (ii) the micro-phenocrysts and (iii) the microlites. Phenocrysts (larger than $1 \mathrm{~cm}$ and interpreted as antecrysts in June 2014; Gurioli et al. 2018) have not been observed in July 2015. 

(An63-69). A compositional gap is observed between the two populations (Fig. 8a). Some of the July 2015 microphenocrysts of plg are reversely zoned (from $\mathrm{An}_{75}$ in the cores to $\mathrm{An}_{80}$ in the rims, see $\mathrm{c}_{1}-\mathrm{r}_{1}$ and $\mathrm{c}_{2}-\mathrm{r}_{2}$ couples in Fig. 8a and Table S4). This reverse zoning has been only observed on plg micro-phenocrysts. compositions within a narrow range of composition $\left(\mathrm{En}_{48-40} \mathrm{Fss}_{-14} \mathrm{Wo}_{42-46}\right.$; Table S4). The populations of cpx microlite and micro-phenocryst can be distinguished for their $\mathrm{TiO}_{2}$ content and the percentage of the tetrahedral sites occupied by $\mathrm{Al}$ (Fig. 8b), called $\mathrm{Al}(\mathrm{z})$. Micro-phenocrysts have low $\mathrm{TiO}_{2}$ content and $\mathrm{Al}(\mathrm{z})$ (between 0.7 and 1.5 of $\mathrm{TiO}_{2}$ wt $\%$; between 3 and $7 \%$ for $\mathrm{Al}(\mathrm{z})$ ), while microlites exhibit the highest values (between 1.5 and 4 of $\mathrm{TiO}_{2} \mathrm{wt} \%$; between 7 and $17 \%$ for $\left.\mathrm{Al}(\mathrm{z})\right)$. A change in the slope of the increasing trend of $\mathrm{Al}(\mathrm{z})$ and $\mathrm{TiO}_{2}$ content is observed. This trend was already observed in the other PdF products and attributed to the effect of enhanced plg crystallization (Al-rich) on the melt composition (Boivin and Bachèlery 2009; Di Muro et al. 2015). micro-phenocrysts and $\mathrm{Fo}_{76-77}$ for microlites (Fig. 8c and Table S4).

\subsubsection{Bulk rock, glass analyses} wt $\% ; \mathrm{K}_{2} \mathrm{O}: 0.7-0.8 \mathrm{wt} \% ; \mathrm{CaO} / \mathrm{Al}_{2} \mathrm{O}_{3}: 0.7-0.8$; red box in Fig. 9a; Table S4). In the frame of the 2014-2015 sequence of eruptions, the products of June 2014, February and May 2015 events were evolved basalts (Coppola et al. 2017) from an initial magma input that occurred in November 2009. Hydrous experimental compositions performed by Brugier (2016) show a marked decrease in $\mathrm{CaO} / \mathrm{Al}_{2} \mathrm{O}_{3}$ at $\mathrm{T}<1150^{\circ} \mathrm{C}$ (ol crystallization above this temperature, with the occurrence of ol, cpx then plg below this temperature) and reproduce relatively well the natural bulk rock compositions from December 2009 to May 2015 by decreasing temperature from 1200 to $1100{ }^{\circ} \mathrm{C}$ (Fig. 9b). A reverse trend is then observed since the July 2015 eruption with a progressive increase of the $\mathrm{CaO} / \mathrm{Al} 2 \mathrm{O} 3$ and $\mathrm{MgO}$ content until the August-Ocotber 2015 magmas (Fig. 9a; Coppola et al. 2017). (close to that of the bulk rock) and an average $\mathrm{MgO}$ content of $5.8 \mathrm{wt} \%$ (slightly lower than the bulk rock). This difference can be explained by the occurrence of a small amount of micro-phenocrysts of ol (ca. 2 wt $\%$ ) within the bulk rock. $\mathrm{MgO}$ content (controlled by the micro-crystallization of ol) and $\mathrm{CaO} / \mathrm{Al}_{2} \mathrm{O}_{3}$ ratio (controlled by the 
micro-crystallization of plg and cpx) of interstitial glasses decrease from the golden, to the fluidal, to the spiny clasts (Fig. 9c; Table S4). Microlite-rich spiny opaque clasts have the most evolved interstitial glasses (from 4.2 to $5.3 \mathrm{wt} \%$ in $\mathrm{MgO}$ and from 0.71 to 0.78 for $\mathrm{CaO} / \mathrm{Al}_{2} \mathrm{O}_{3}$ ). Matrix in lavas have similar compositions to the fluidal scoria. The July 2015 tephra glass compositions mimic those found in the June 2014 eruption (Gurioli et al. 2018).

\subsubsection{Phase equilibria}

Plg microlites observed in the July 2015 products are in equilibrium with their matrix $\left(\mathrm{K}_{\mathrm{D}}=0.29\right.$ on average), and most of the plg micro-phenocrysts (included the reversely zoned plg) are in equilibrium with the hybrid bulk rock (average $K_{D}=0.22$ ). Plg micro-phenocryst of July 2015 with relatively high anorthite (> $A n_{82}$ ) might be considered as antecrysts because they do not fulfil the equilibrium conditions with the bulk rock (like the high Fo olivine in the June 2014 magma). The cpx micro-phenocrysts are in equilibrium $\left(\mathrm{K}_{\mathrm{D}}=0.24\right.$ in average) with the bulk rock as well as the microlites with their matrix $\left(\mathrm{K}_{\mathrm{D}}=0.28\right.$ in average). Both ol microlites and microphenocrysts are in equilibrium with their surrounding glass $\left(\mathrm{K}_{\mathrm{D}}=0.28\right.$ in average $)$ and bulk rock $\left(\mathrm{K}_{\mathrm{D}}=0.28\right.$ in average), respectively.

\subsection{Temperature and $\mathrm{H}_{2} \mathrm{O}$ content}

Microlites content of the different eruptive component increase progressively from the golden pumice to the fluidal scoria to finally the spiny scoria. Moreover, the $\mathrm{K}_{2} \mathrm{O}$ (incompatible element) content decrease from the bulk rock ( $0.74 \mathrm{wt} \%$ in average), to the golden pumice ( $0.89 \mathrm{wt} \%$ in average), to fluidal scoria and lava ( $0.96 \mathrm{wt} \%$ in average), to finally the spiny scoria (1.07 wt $\%$ in average). We thus suggest that (i) the bulk-rock represent the microlite-free and pre-eruptive conditions end-member, (ii) whereas the fluidal, lava and spiny components represent the microlite-rich and syn-eruptive conditions end-member, with golden pumice representing the beginning of the crystallization of the melt during the ascent of the magma and the transition between the pre and syn-eruptive conditions. Using the newly calibrated hydrous thermometer to constrain pre-eruptive conditions (Fig. S2), we calculated temperatures from $1171{ }^{\circ} \mathrm{C}$ for the November 2009 most mafic bulk magma composition to $1114{ }^{\circ} \mathrm{C}$ for the February and May 2015 bulk magma compositions. Calculated June 2014 and July 2015 bulk magma temperatures are 1124 and $1121^{\circ} \mathrm{C}$ respectively. The average temperature of the golden pumice magma component, which is thought to also correspond to pre-eruptive melt conditions, is $1103 \pm 4{ }^{\circ} \mathrm{C}$ (Fig. 10). These bulk magma and golden pumice temperatures are fully consistent with the temperature of crystallization of ol and cpx in equilibrium within the hydrous experiments of Brugier (2016). Temperatures of the other component (fluidal scoria, spiny scoria and lavas), which we considered as mainly degassed, are calculated using the newly 
calibrated dry thermometer (Fig. S2). Average temperature range from $1137 \pm 6{ }^{\circ} \mathrm{C}$ for fluidal scoria and typical lavas to $1128 \pm 6$ and $1127 \pm 9^{\circ} \mathrm{C}$ for spiny-glassy and spiny-opaque respectively (July 2015 eruption). Calculated temperatures of the vesicle-rich lava (plug of the lava flow) and dense lava (margin of the lava flow) are respectively $1138 \pm 3{ }^{\circ} \mathrm{C}$ and $1126 \pm 2{ }^{\circ} \mathrm{C}$.

$\mathrm{H}_{2} \mathrm{O}$ calculations were performed on plg crystals and melts on equilibrium (Table S4). (i) Equilibrium between plg micro-phenocrysts and bulk rock compositions lead to relatively high $\mathrm{H}_{2} \mathrm{O}$ content of $1.1 \pm 0.3$ wt $\%$ (using pre-eruptive parameters of $1121^{\circ} \mathrm{C}$ and $50 \mathrm{MPa}$ ) which are consistent with the dissolved $\mathrm{H}_{2} \mathrm{O}$ content in Brugier (2016) $50 \mathrm{MPa}$ experiments (0.5 to $1.6 \mathrm{wt} \%$ ) and with PdF pre-eruptive conditions (Di Muro et al. 2014, 2016). (ii) Golden pumice water content can be estimated using the equilibrium between plg microlites and surrounding glass compositions. With this assumption, $\mathrm{H}_{2} \mathrm{O}$ content values between $0.8 \pm 0.3 \mathrm{wt} \%$ have been found using pre-eruptive parameters $\left(1103{ }^{\circ} \mathrm{C}\right.$ and $\left.50 \mathrm{MPa}\right)$. The $\mathrm{H}_{2} \mathrm{O}$ contents of the other eruptive components (fluidal scoria, spiny scoria and lavas) are estimated using the equilibrium between plg microlites and surrounding glass compositions, with syn-eruptive and atmospheric conditions. It leads to an average $\mathrm{H}_{2} \mathrm{O}$ of $0.4 \pm 0.3$ wt $\%$.

\section{Discussion}

\subsection{Componentry evolution with magma output rates and eruptive dynamics}

Textural and chemical features of the juvenile samples collected during the different eruptions, are representative of the magma at fragmentation. The exception is represented by the spiny-opaque fragments which are interpreted as recycled, composite juvenile products (Gurioli et al. 2018). We also assume that the sampling procedure is statistically representative of the on-going eruptive activity at the time of the sampling. Therefore we can infer some important conclusions.

The chronological evolution of the componentry of the material emitted during the first four eruptions of the 2014-2015 period, mirrors the progressive TADR decrease (Fig. 3) and the eruptive dynamics evolution (Fig. 2). (i) Vesicular fluidal scoria (800 kg m³ ; Fig. 4a) is preferentially emitted at the beginning of the eruptions, correlated with the TADR peaks and with mild lava fountains (Hawaiian-style activity; Fig. 2a, 2b and 2c). (ii) Denser spiny scoria (1300 kg m²; Fig. 4a) emissions preferentially occur afterwards and at the end of these eruptions, correlated with the TADR decrease and a Strombolian-style activity; Fig. 2d). Thus, the vesicle content within the eruptive products decreases with the decreasing of TADR, eruptive intensity and time. 

The vesicular golden pumice $\left(800 \mathrm{~kg} \mathrm{~m}^{-3}\right)$ are in fact only present in the June 2014 eruption and just one single fragment has been found in the July 2015 deposits. These golden pumice occurred during the TADR peak at the beginning of the eruptions. During the June 2014 eruption, a $100 \%$ crystallized and dense $\left(1800 \mathrm{~kg} \mathrm{~m}^{-3}\right)$ lava was extruded as well. Gurioli et al. (2018) interpreted these features as derived from a second boiling mechanism which segregated the exsolved gas (golden pumice) and the crystals (lava) within the shallow reservoir and triggered the eruption. Therefore, the highly vesicular golden pumice occurrence is not necessarily linked with the eruptive intensity, as the June 2014 eruption was relatively low in terms of TADR and emitted volume compared to the other eruptions (Fig. 3). On the other side, the fact that these end-member products (vesicular and crystal-free golden pumice vs. dense and crystal-full lava) are no longer observed in the following eruptions of February, May and July 2015 eruptions, evidence the occurrence of different trigger mechanisms than the June 2014 eruption as well as different cooling conditions of the shallow reservoirs.

\subsection{Pre-eruptive shallow magmatic reservoir conditions}

Natural and experimental melt compositions (Figs. 9a and 9b) coupled with micro-phenocrysts sizes (Fig. 7a), contents (Fig. 7b) and compositions (Fig. 8) of juvenile fragments are the main direct measurements to gain information on the pre-eruptive conditions of the eruptions. First, experimental melt composition evolution from Brugier (2016) support the idea of Coppola et al. (2017) and Gurioli et al. (2018) that the June 2014 magma, as well as the February and May 2015 magmas, are chronologically inherited from the differentiation of the November 2009 parental magma (Fig. 9b). However, Coppola et al. (2017) highlight the fact that the MgO content and $\mathrm{CaO} / \mathrm{Al}_{2} \mathrm{O}_{3}$ ratio of the July 2015 bulk rock composition (6.44 wt \% and 0.77 respectively) is slightly higher, than those of the May 2015 one (6.18 wt\% and 0.74; Fig. 9a). Therefore, these authors interpret the July 2015 bulk rock composition as representative of a hybrid magma resulting from a process of magmatic rejuvenation of the shallow system of PdF. Again, these observations suggest that the June 2014 and the July 2015 eruptions were triggered by different pre-eruptive processes.

Two crystal populations are clearly visible on the CSD performed on the eruptive products of both June 2014 and July 2015 eruptions (Fig. 7a). The first crystal population of relatively small size $(<1.2 \mathrm{~mm})$ and high slope represents the microlite population and will be discussed in the section hereafter. The second crystal population represents the micro-phenocrysts, with lower CSD slopes and larger sizes, and may give us some 
a partial pre-eruptive rejuvenation. (i) Some of the July 2015 plg micro-phenocrysts record reverse zoning (Fig. 8a) and (ii) rare plg micro-phenocrysts has been measured with a very high anorthite content $\left(\mathrm{An}_{85}\right.$; Fig. 8a) that may be inherited from a new relatively low differentiated magmatic input. (iii) The incapability of the hydrous experiments to reproduce calcic plg composition may also suggest that they result from a magma hybridisation micro-phenocrysts are observed compared to those of June 2014 (Fig. 8c) and (v) rare resorbed features are observed on the July $2015 \mathrm{ol}$ micro-phenocrysts (Fig. 5e), which is consistent with the input of a relatively hot $\left(1144^{\circ} \mathrm{C}\right)$ mafic magma into a dominantly cold $\left(1114^{\circ} \mathrm{C}\right)$ differentiated magma. Finally, (vi) we suggest that the surprisingly high temperature range measured in the July 2015 lava matrix actually records the pre-eruptive hybridisation processes. Again, all these results are coherent with the idea of Coppola et al. (2017) that suggest that the July 2015 magma is the result of a mixing between $65-75 \%$ of a differentiated magma and $25-35 \%$ of less differentiated magma. Moreover, the cooling hydrous experiments of Brugier (2016) confirm that the natural evolved basalts emitted between December 2009 and May 2015 are formed by progressive cooling and crystallization of a former magma recharge occurred in November 2009 (Fig. 9b). CSDs also suggest that the June 2014 micro-phenocrysts are larger (up to $8 \mathrm{~mm}$ in length) than the July 2015 one (4 $\mathrm{mm}$ in length), which is in agreement with a more mature and relatively crystal-richer shallow reservoir for the June 2014 eruption. (50 $\mathrm{MPa}$ and dissolved $\mathrm{H}_{2} \mathrm{O}$ from 0.5 to 1.6 wt\% within experimental samples; black line in Fig. S2) leads to relatively low pre-eruptive temperatures of 1103 (golden pumice) to $1121{ }^{\circ} \mathrm{C}$ (bulk rock) for July 2015 , mostly because the $\mathrm{H}_{2} \mathrm{O}$ content dissolved in the pre-eruptive magmas tends to decrease the magma temperature. Moreover, $\mathrm{H}_{2} \mathrm{O}$ calculations with the plg micro-phenocrysts/bulk rock equilibrium lead to relatively high $\mathrm{H}_{2} \mathrm{O}$ content in the natural samples ( 0.8 to $1.5 \mathrm{wt} \% \pm 0.3,1.1 \mathrm{wt} \%$ in average) that show that the micro-phenocrysts form under undegassed (saturated) and pressurized conditions, by cooling-driven crystallization.

\subsection{Syn-eruptive conduit processes}

Micro-texture as VSD (Fig. 6a), microlite sizes (Fig. 7a), contents (Fig. 7b) and compositions (Fig. 8), as well as glass compositions (Fig. 9c) are the most relevant parameters that we can measure from the eruptive products to track the syn-eruptive conduit processes.

First, VSDs show an initial unimodal vesicle population within the golden pumice and fluidal scoria (Fig. 6a), which represent vesicle nucleation and growth mostly within the eruptive dyke during the initial phases of 
both June 2014 and July 2015 eruptions, when the TADR were still relatively high and coupled with Hawaiianstyle activity. In the June 2014 golden pumice, vesicle nucleation also occur before the eruption as Gurioli et al. (2018) interpreted this highly vesiculated component as the product of a pre-eruptive second boiling mechanism. Then, the VSDs within the spiny-scoria and typical lavas are characterized by two different modes. These latter modes represent an episode of vesicle nucleation and growth (for the small size vesicles, occurring in the golden pumice and fluidal scoria as well) followed in time by the formation of large vesicles (up to $1 \mathrm{~cm}$ in diameter) by coalescence. This coalescence phase is probably enhanced by slow ascent of the magma in the conduit, coinciding with low TADR and Strombolian-style dominantly effusive activity. Moreover, we observe within the pyroclasts two positive correlation trends between $\mathrm{N}_{\mathrm{V}}$ and $\mathrm{V}_{\mathrm{G}} / \mathrm{V}_{\mathrm{L}}$, with distinct slopes (Fig. 6b). These two trends are mostly explained by bubble coalescence associated with gas loss. Vesicle coalescence within the collected samples is also highlighted by the He vesicle connectivity measurements (Fig. 4b) where vesicles of the spiny scoria and lavas are more connected ( 0 to 15 vol\% of isolated vesicles) than in the golden pumice and fluidal scoria ( 0 to 40 vol\% of isolated vesicles). All these observations explain the transition between an initial closed degassing system dominated by relatively high TADR and high magma ascent rates (producing golden pumice and fluidal scoria) with an open system degassing dominated by relatively low TADR and low magma ascent rates (producing spiny scoria). This interpretation is also coherent with the decrease of $\mathrm{Nv}$ from golden to spiny fragments that should reflect a decrease of the decompression rate (Toramaru 2006; Table S3): considering all the vesicles of each erupted component and assuming that they form in the conduit (which may not be accurate for the June 2014 golden pumice), the model permits to calculate maximum decompression rates at the beginning of the eruptions during Hawaiian-style activities (0.08 MPa.s $\mathrm{s}^{-1}$ for the July 2015 golden pumice), whereas lower decompression rates are calculated for latter Strombolian-style activities (between of 0.03 and $0.05 \mathrm{MPa}_{\mathrm{s}}^{-1}$ for spiny-glassy scoria of the July 2015 and June 2014 eruptions respectively). These decompression rates are typically similar than those estimated in basaltic eruptions with dyke radius around $1 \mathrm{~m}$ (Shea 2017).

The presence of isolated vesicles in golden pumice and fluidal scoria suggest also that these erupted products are naturally quenched in a relatively hot surface environment (lava fountaining thermal environment) whereas the spiny scoria are quenched in a colder environment (colder Strombolian explosions environment) where brittle mechanisms may occur (rock cracking that connect the vesicles).

Similarly to decompression rate meter of Toramaru (2006), we applied the $\mathrm{N}_{\mathrm{C}}$ water exsolution rate meter of Toramaru et al. (2008; Table S3). Calculated water exsolution rates are decreasing from the golden pumice (2.1 and $2.210^{-4} \mathrm{wt}^{-1} \mathrm{~s}^{-1}$ for the July 2014 and June 2015 eruptions respectively) to spiny-glassy scoria (2.8 and 5.8 


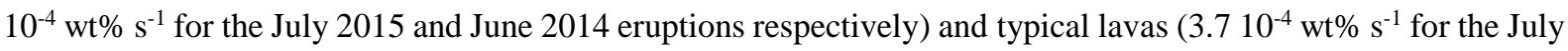
2015 eruption). On the other hand, and thanks to pre-eruptive seismic spectrograms (Aki and Ferrazzini 2000; Battaglia et al. 2005; Peltier et al. 2005; Roult et al. 2012), we can estimate an average initial magma residence time within the dyke of $40 \mathrm{~min}$ and $55 \mathrm{~min}$ for the June 2014 and July 2015 eruptions respectively (Fig. S3). Thus total exsolved $\mathrm{H}_{2} \mathrm{O}$ contents from the melt are increasing from the Hawaiian (between 0.5 and $0.7 \mathrm{wt} \%$ for the both eruptions) to the Strombolian products (between 0.9 and $1.4 \mathrm{wt} \%$ for spiny-glassy scoria of the June 2014 and July 2015 eruptions respectively) and typical lavas (1.2 wt\% for the July 2015 eruption).

The microlites population (which is volumetrically dominant) is identifiable in the CSD thanks to its higher slope and smaller size (Fig. 7a). These microlites are in equilibrium with their surrounding matrix, with relatively low anorthite content for plg $\left(\mathrm{An}_{63-69}\right.$; Fig. 8a), high $\mathrm{Al}(\mathrm{z})$ and $\mathrm{TiO}_{2}$ content for $\mathrm{cpx}(>8$ and $>1.5 \mathrm{wt} \%$ respectively; Fig. 8b) and low forsterite content for ol ( $\mathrm{Fo}_{71-77}$; Fig. 8c). Eruptive temperature estimated by using the dry $\mathrm{MgO}$-thermometer (blue line in Fig. S2) leads to syn-eruptive temperatures between 1116 and $1139{ }^{\circ} \mathrm{C}$ for July 2015 depending on the components. Most of these syn-eruptive temperatures are higher than the pre-eruptive temperature estimations because this calibration is based on totally degassed melts and because latent heat of crystallization due to the micro-crystallization may also play a role. However, we hypothesize that the higher temperature range measured in the lava matrix actually reflects the pre-eruptive hybridisation processes. $\mathrm{H}_{2} \mathrm{O}$ content calculations with plg microlites/matrix equilibrium leads to variable but lower $\mathrm{H}_{2} \mathrm{O}$ content (between 0.1 and $0.8 \mathrm{wt} \%$ of $\mathrm{H}_{2} \mathrm{O}, 0.4 \mathrm{wt} \%$ in average) compared to the pre-eruptive conditions. This support the hypothesis that plg and cpx microlites form under variable and partially degassed and sub-surface conditions, by degassingdriven crystallization within the dyke. We also suggest that ol microlites form by cooling-driven crystallization under relatively low melt temperatures $\left(<1130{ }^{\circ} \mathrm{C}\right)$ and under atmospheric conditions. Moreover, the maximum lengths (as well as width, which is not measured by the CSD) of microlites and crystal number density (table S3) globally increase with decreasing vesicularity, which is coherent with a progressive increase of the residence time of the magma in the eruptive dyke.

When a magma is decompressed and is migrating toward the surface, degassing models (Lesne et al. 2011; Di Muro et al. 2016; Shea 2017) suggest that basaltic melts start their main exsolving and heterogeneous nucleation phase around $1 \mathrm{~km}$ below the surface. Thus, according these degassing models and for magmatic reservoir deeper than $1 \mathrm{~km}$, vesicle nucleation and associated degassing-driven crystallization (Applegarth et al. 2013) may not start at the very beginning of the magma ascent towards the surface. During the June 2014 and July 
2015 cases, this delay may be represented by the compositional gap between the micro-phenocrysts and the microlites (Fig. 8).

Finally, the crystal nucleation densities $\mathrm{N}^{0}$ are quite stable for each eruption, except for the spiny-opaque components where they drastically increase for plg. This support the idea that the spiny-opaque scoria are juvenile but recycled products because plg microlites may form within the eruptive vents after the fragmentation. Their low vesicle content and evidences of bubble coalescence (irregular contours associated with low $\mathrm{N}_{\mathrm{V}}$ and $\mathrm{V}_{\mathrm{G}} / \mathrm{V}_{\mathrm{L}}$ ) also highlight subsurface degassing that may occur during a recycling mechanism. Concerning lava samples, we were able to evidence bubble segregation mechanism within the lava flow, highlighted by the sharp increase in the $\mathrm{V}_{\mathrm{G}} / \mathrm{V}_{\mathrm{L}}$ ratio from the typical and dense samples to the vesiculated one (Fig. 7), corresponding to vesicle gain because of the bubble nucleation and/or segregation at the surface.

\subsection{Implications on the eruptive styles and comparison with other basaltic systems}

Pre-and syn-eruptive processes, controlling the volatile and crystal contents of the magma which govern the magma viscosity (Giordano and Dingwell 2003) and fragmentation mechanisms (Edmonds and Wallace 2017), are dependent on the geometry of the magmatic systems and magma paths towards the surface that are more or less different from one volcano to another (Michon et al. 2015; Peltier et al. 2015). At PdF, pre-eruptive magmas contain a moderate content in dissolved water (up to $1.4 \mathrm{wt} \%$; Di Muro et al. 2014, 2016) and are generally stored within multiple and relatively shallow levels, between a few hundred meters (multitude of small magma pockets) up to $3 \mathrm{~km}$ (main reservoir) bellow the summit craters (Peltier et al. 2008, 2015, 2016). In contrast, pre-eruptive Kilauea magmas have slightly lower water content (less than 1 wt\%; Gerlach 1986; Wallace and Anderson 1998) and are stored within two main reservoirs located between 2 and $3 \mathrm{~km}$ below the summit caldera (Edmonds et al. 2013; Peltier et al. 2015). At Etna, pre-eruptive magmas are stored within multiple levels spanning a wider range of depth (from 1 to $10 \mathrm{~km}$ deep) than PdF and Kilauea (Patanè et al. 2008; Aloisi et al. 2011; Bonaccorso et al. 2013; Peltier et al. 2015), and contain relatively high water content (up to 2.3 wt\%; Métrich and Rutherford 1998; Giordano and Dingwell 2003).

During the June 2014-July 2015 period at PdF, we suggest that the efficient syn-eruptive degassing, the moderate micro-crystallization, the relatively low volume of erupted magmas and the lack of an important continuous re-filling of fresh, volatile-rich magma do not allow the formation of sustained and energetic lava fountains. In contrast at Kilauea, althought a relatively low content of dissolved water in the melt, major basaltic eruptions, implying relatively large magmatic supplies and volumes, are generally associated with relatively high 
decompression rates, low syn-eruptive degassing and low degassing-driven crystallization, generating sustained and intense lava fountains (e.g. Head and Wilson 1987, 1989; Mangan and Cashman 1996; Parfitt 2004; Stovall et al. 2011, 2012; Parcheta et al. 2013; Holt et al. 2019). At Etna, petrological and geochemical investigations suggest that the initial volatile-rich magmas associated with relatively efficient degassing processes towards the surface can sometimes lead to crystal-rich and viscous magmas near the fragmentation level (Métrich and Rutherford 1998), generating violent Strombolian activities (Polacci et al. 2019). On this volcano, syn-eruptive transitions between Hawaiian-style and more violent activities have also been largely documented, but contrary to PdF, these transitions were mainly from Strombolian-style to Hawaiian-style activity (e.g. Polacci et al. 2006; Sable et al. 2006; Corsaro et al. 2017; Pompilio et al. 2017; Edwards et al. 2018). According to these latter authors, this evolution is marked by the same textural signatures of the emitted products as in our study, where the degassed Strombolian products are more crystalline and less vesiculated than their Hawaiian counterparts. In the early 2000, the volcanic system of Etna was fed by a magmatic system progressively more degassed whose volatile exsolution caused bubble coalescence and the formation of slugs that burst into the typical Strombolian explosions, fragmenting a melt having experienced prolonged residence at depth (Polacci et al. 2006). The transition to fire fountain activity occurred when coalescence became so efficient to produce a foam of gas bubbles that eventually collapsed, rose in the conduit as a gas core surrounded by a moderately vesiculated liquid annulus, and erupted explosively as vigorous jets of gas and liquid magma (Polacci et al. 2006; Andronico and Corsaro 2011). Alternatively, Houghton et al. (2004), Sable et al. (2006) and Pompilio et al. (2017), suggest that the transition between weak intracrater Strombolian activity and paroxysmal phases with several km-high sustained columns, could be related to different proportions, within the conduit, between high (microlite-rich) and low (microlite-poor and gas rich) viscosity magma portions. In both cases the contrasting textures of the pyroclasts are not genetically related to each other. In our case at PdF, we suggest that the eruptive dynamics evolution is controlled by distinct processes with respect of those described in these latter papers, at least in eruptions in which moderate Hawaiianstyle activity precedes Strombolian-style activity (Fig. 10). In these cases, the textural variation is related to the same batch of magma undergoing different cooling and degassing histories.

\section{Conclusions on the eruptive models and fragmentation implications}

From all the observations and interpretations brought by this multi-disciplinary work, we are able (i) to reconstruct the pre-eruptive conditions of the PdF shallow magmatic system for the June 2014-July 2015 period, 
(ii) to quantify the implications for the syn-eruptive processes within the eruptive dykes and (iii) to correlate the previous points with the eruptive dynamics and emitted products (Figs. 10a and 10b).

The reactivation of the shallow plumbing system of PdF in June 2014, followed by the beginning of its

654

655

656

657

658

659

660

661

662

663

664

665

666

667

668

669

670

671

672

673

674

675

676

677

678

679 rejuvenation since early 2015 imply several changes in the shallow magmatic reservoirs at PdF. The June 2014 evolved magma was reactivated by internal magmatic processes. This reactivation was probably triggered by a second boiling and a gas/crystal segregation (golden pumice vs. crystallized lava) within the magmatic volume that increase the internal overpressure of this reservoir at the origin of the eruption (Gurioli et al. 2018). This is consistent with low intensity precursors and weak inflation rate preceding the eruption (Peltier et al. 2016). On the other hand the July 2015 eruption erupt a less physically stratified magma (scarce golden pumice and absence of fully-crystallized end-member) inherited from a mixing between a differentiated magma and a less differentiated one. This new magmatic input of pristine magma is consistent with a relatively strong summit ground inflation preceding this eruption (Peltier et al. 2016).

Pre-eruptive reservoir conditions are more or less impacting the syn-eruptive processes that occur within the eruptive dykes. In June 2014, the pre-eruptive gas segregation accumulated a foam, which probably provoked an annular dominated flow within the dyke (Jaupart and Vergniolle 1998, 1989; Vergniolle and Jaupart 1990). However, Hawaiian-style activity is also observed without significant golden pumice emission, as in the July 2015 eruption. Less continuous conduit gas flow as churn flow (Houghton and Gonnerman 2008), associated with a high vesicle nucleation rate can also produce mild lava fountains and might occur during the fluidal scoria emission. Finally, we suggest that discontinuous slug flow (open system degassing) are the most relevant flow regime for Strombolian phases at the end of the PdF eruptions.

Estimated initial residence time durations within the eruptive dyke, thanks to the seismic spectrograms, are coherent with shallow reservoir depths estimated between 1.3 and $1.7 \mathrm{~km}$ below the volcano top by Peltier et

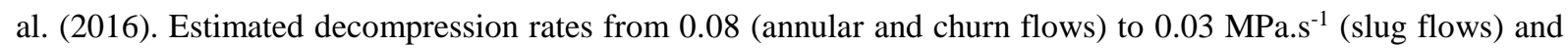
are also coherent with melt inclusion saturation pressure measured by Di Muro et al. (2014 and 2016). According to the Gonnermann and Manga (2013) model (Fig. 10c), these decompression rates, which can be related to corresponding TADR are in agreement with theoretical Hawaiian-style activity assuming typical basaltic viscosities (Villeneuve et al. 2008; Rhéty et al. 2017; Kolzenburg et al. 2018) and with estimated vertical migration of dyke by Peltier et al. (2005) of about 2 to $3 \mathrm{~m} \mathrm{~s}^{-1}$ (assuming a pressure gradient of around $42 \mathrm{MPa} \mathrm{km}^{-1}$ ). Increasing the residence time within the dyke (equivalent to a decreasing of the ascent velocity and to a decreasing 
TADR), associated with an increase of the viscosity because of the increasing microlite content is also consistent

681

682

683

684

685

686

687

688

689

690

691

692

693

694

695

696

697

698

699

700

701

702

703 with Strombolian-style activity associated with effusive emission.

New thermometers are also calibrated in this paper considering pre-eruptive and syn-eruptive conditions that helps (i) understanding the effect of pressure and dissolved gas on the magma temperature evolution before and during an eruption, and (ii) discriminating cooling-driven crystallization from degassing-driven crystallization. Focusing on the pre-eruptive (micro-phenocryst population) and syn-eruptive (microlite population) crystals, it appears that these two populations are very distinct both in terms of CSD and compositions. Further interesting research, (i) as determine the delay between the cooling-driven and degassing-driven crystallizations, and (ii) quantify the residence time of the magma within the dyke for each eruptive styles (based on the CSD theory) should be the new objectives of such research, as this parameters can involve important implications in terms of volatile content and viscosity at the fragmentation levels. (iii) Interesting perspectives of work could also be to compare the acquired petrological data in this study to model for conduit physics.

.

.

.

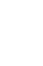



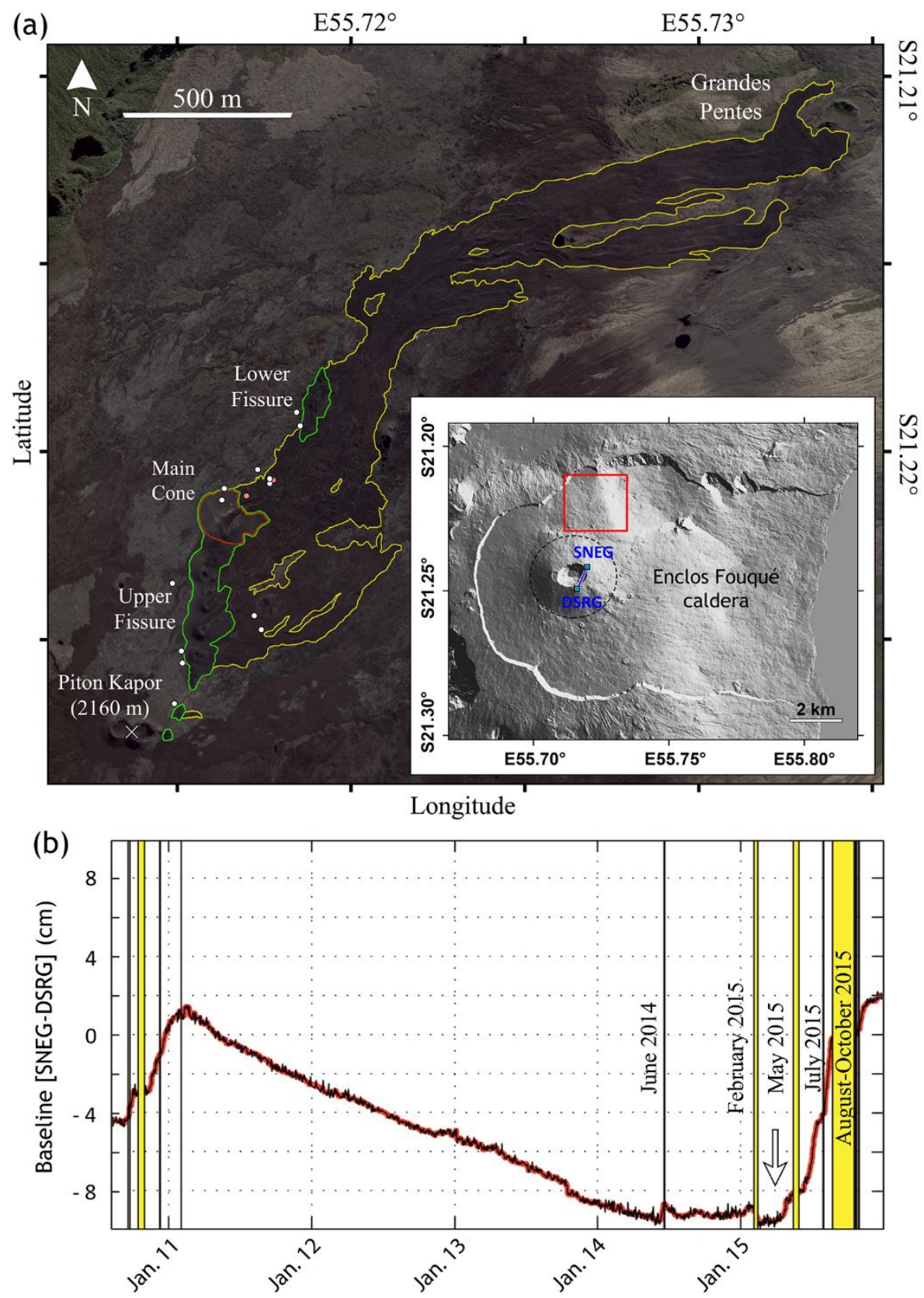

705 Fig. 1 - (a) Digital elevation model (DEM) of PdF and map of the July 2015 eruption. The yellow line shows the outline of the lava flow, the green ones represent both upper and lower eruptive fissures and the red line outline the main cone. White dots represent the different pyroclast sampling sites, red ones show the lava sampling sites. Blue squares and line on the DEM show the summit GNSS baseline [SNEG-DSRG]. Dashed black line represent the central cone of PdF. (b) Summit [SNEG-DSRG] baseline evolution from late 2010 to late 2015 reflecting ground deformation (modified from Gurioli et al. 2018). Eruptive and intrusive activities are materialized by the yellow periods. The vertical arrow represent the main phase of deep seismicity (Peltier et al. 2016). The rapid and strong variations linked to dike injections preceding eruptions have been removed. 


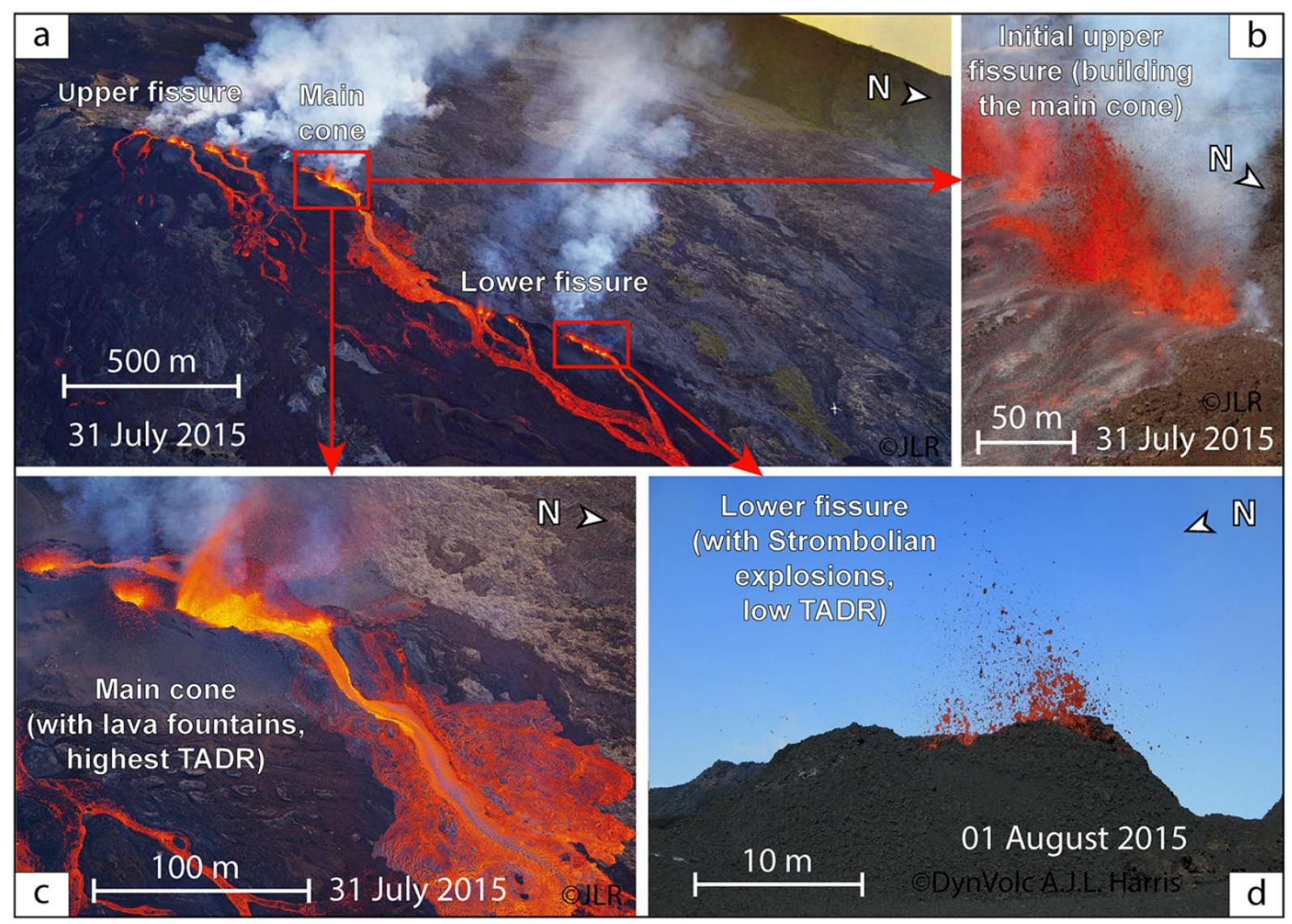

714 Fig. 2 - Pictures of the different eruptive activity during the July 2015 eruption. (a) Aerial picture of the whole 715 eruption site (Journal de La Réunion, JLR 2015-08-01, picture by Hervé Douris). (b) Aerial picture of the initial 716 upper fissure at the very beginning of eruption (JLR, 2015-08-01, picture by Guillaume Cazarré). (c) Aerial 717 picture of the main cone (JLR 2015-08-01, picture by Hervé Douris). The most intense lava fountains can reach 718 several tens of meters in height during the maximum TADR. (d) The TADR is rapidly decreasing and the 719 Hawaiian activity turns in Strombolian-style activity with the burst of large bubbles (picture by A. J. L. Harris). 
(a) June 2014
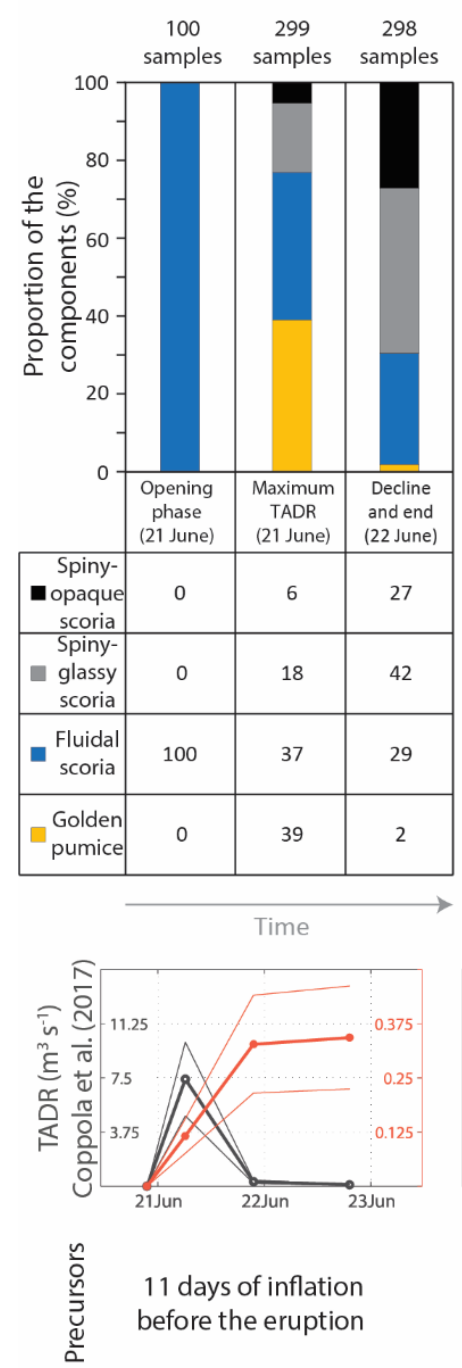

(b) February 2015

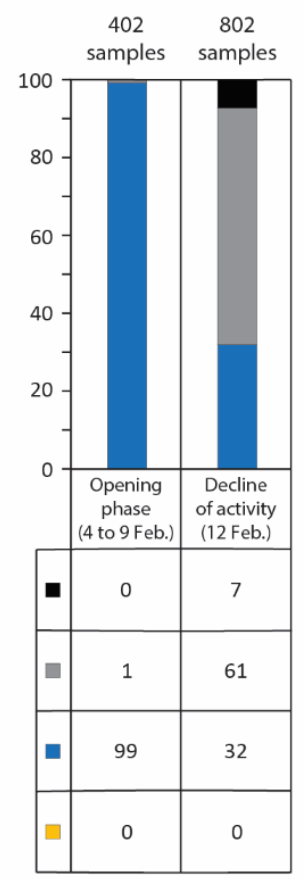

Time

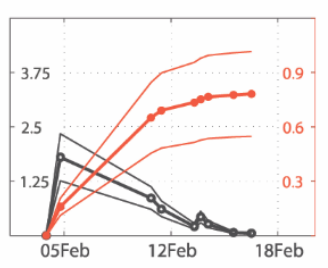

Absence of deflation after the June 2014 eruption (c) May 2015
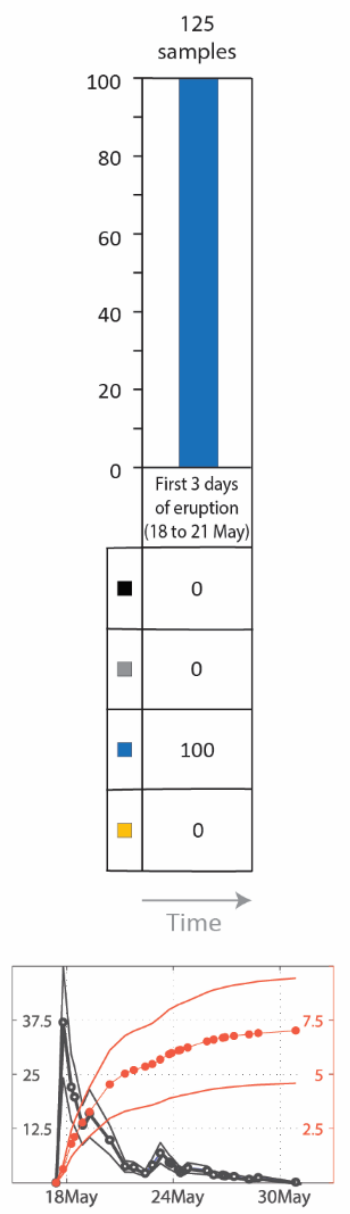

Increase of the inflation rate correlates with deep and intense seismicity since mid-April 2015 (d) July 2015
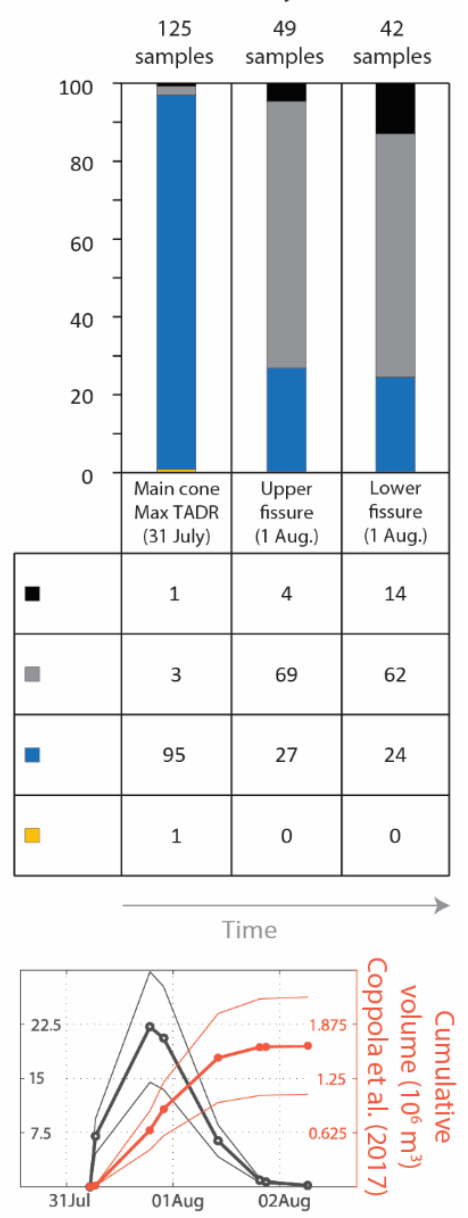

Strong inflation since mid-June 2015 still associated with deep and sparser seismicity

Fig. 3 - Componentry of the eruptive products sampled during the (a) June 2014, (b) February, (c) May and (d) 

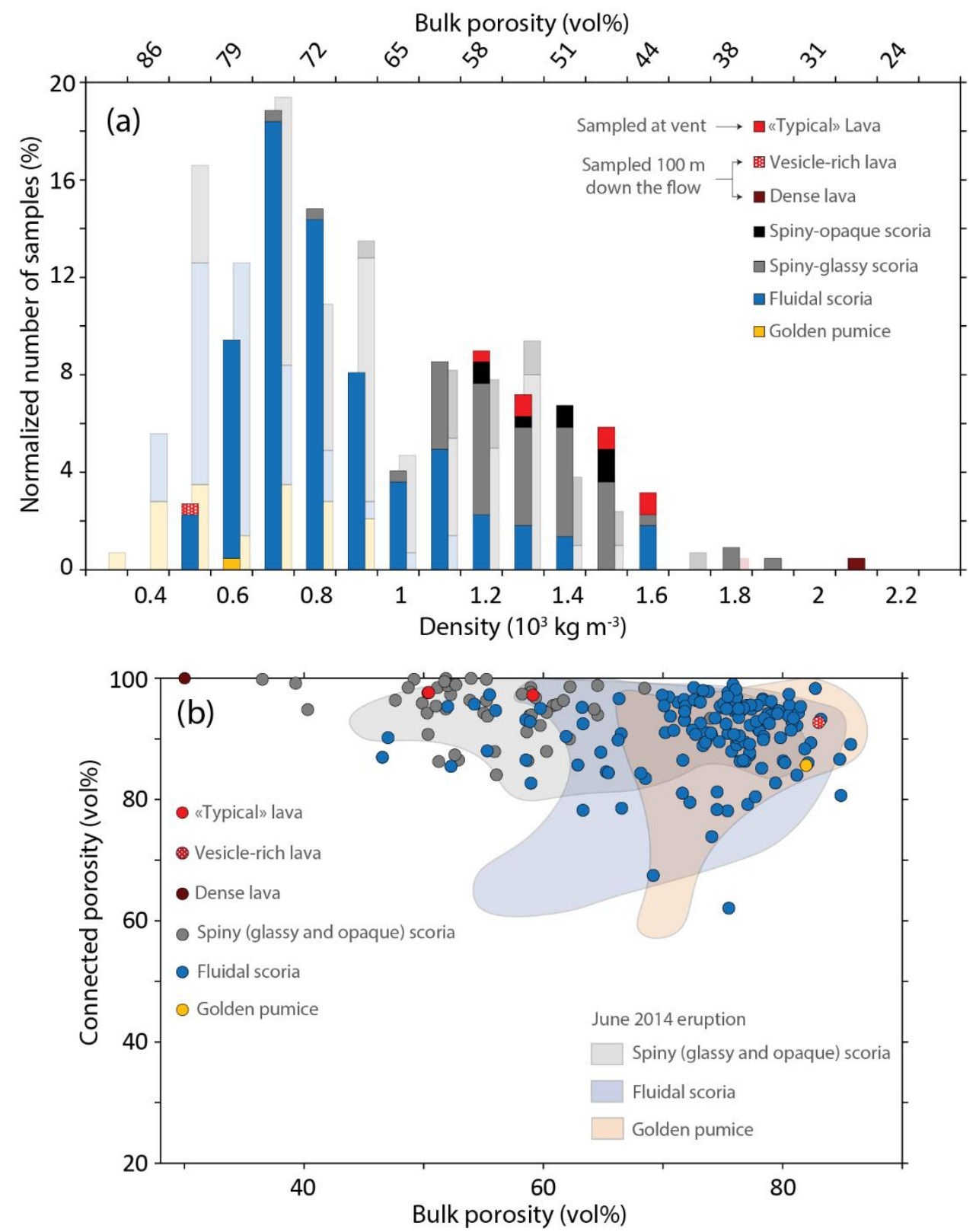

Fig. 4 - (a) Density distribution histogram for the June 2014 (from Gurioli et al. 2018) and July 2015 samples. (b) Connected porosity measured with He for the June 2014 (from Gurioli et al. 2018) and July 2015 samples. The connected porosity is normalized to the total porosity. Fields in the background are datasets from the June 


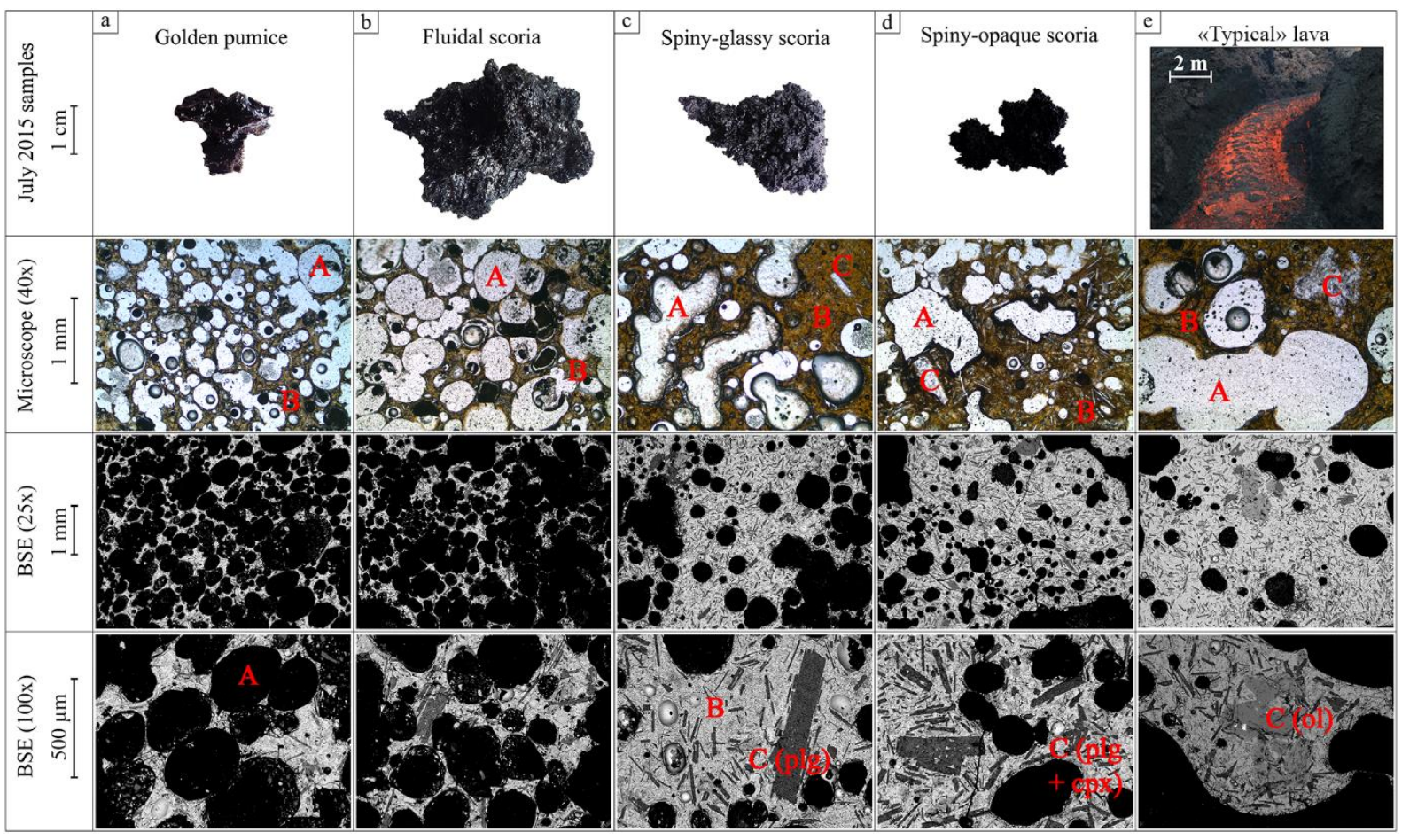

Fig. 5 - General texture of the different July 2015 quenched samples: (a) golden pumice, (b) fluidal scoria, (c) spiny-glassy-scoria, (d) spiny-opaque scoria and (e) typical lava (sampled near the main vent). A is for vesicles, 


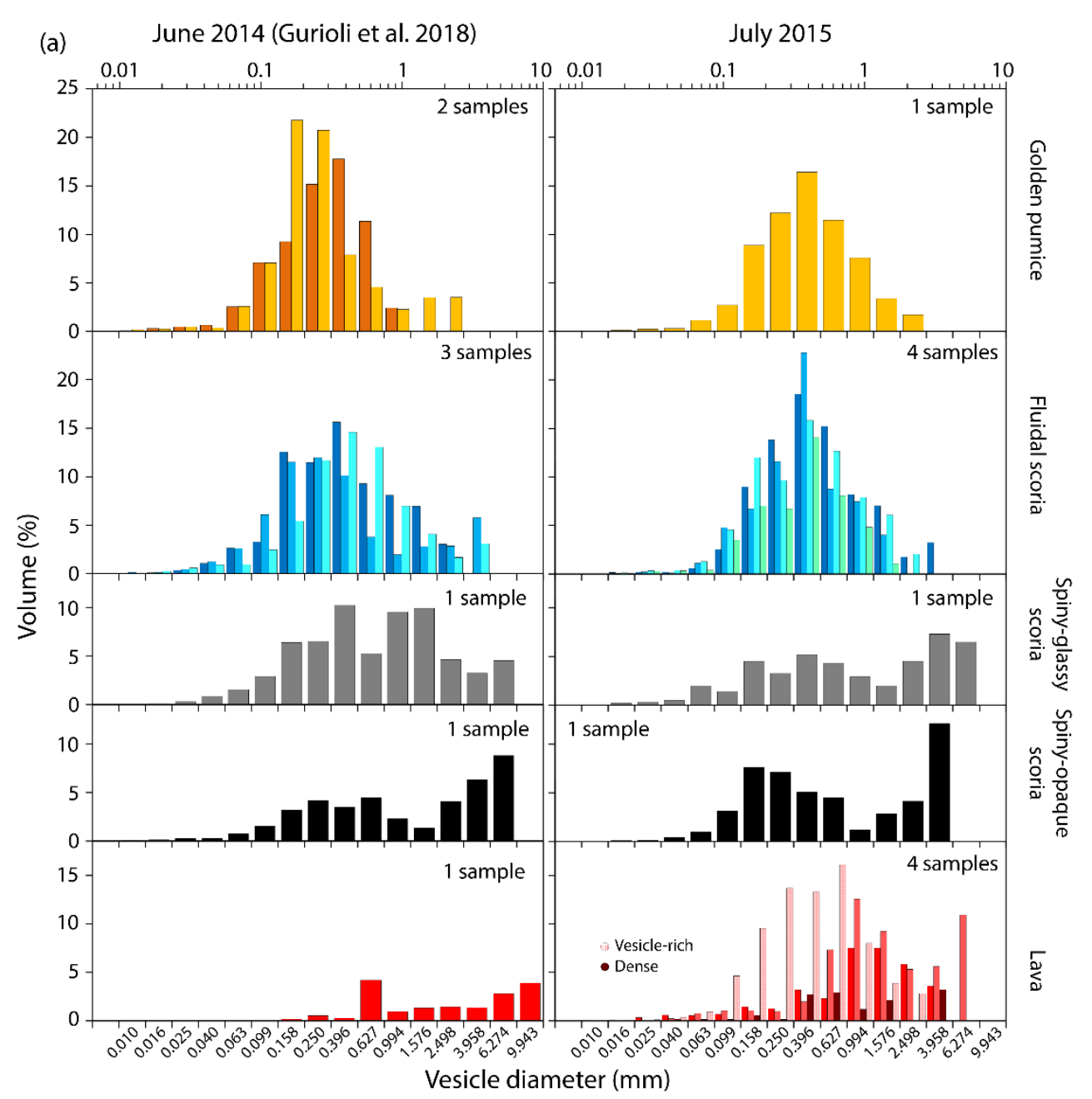

(b)

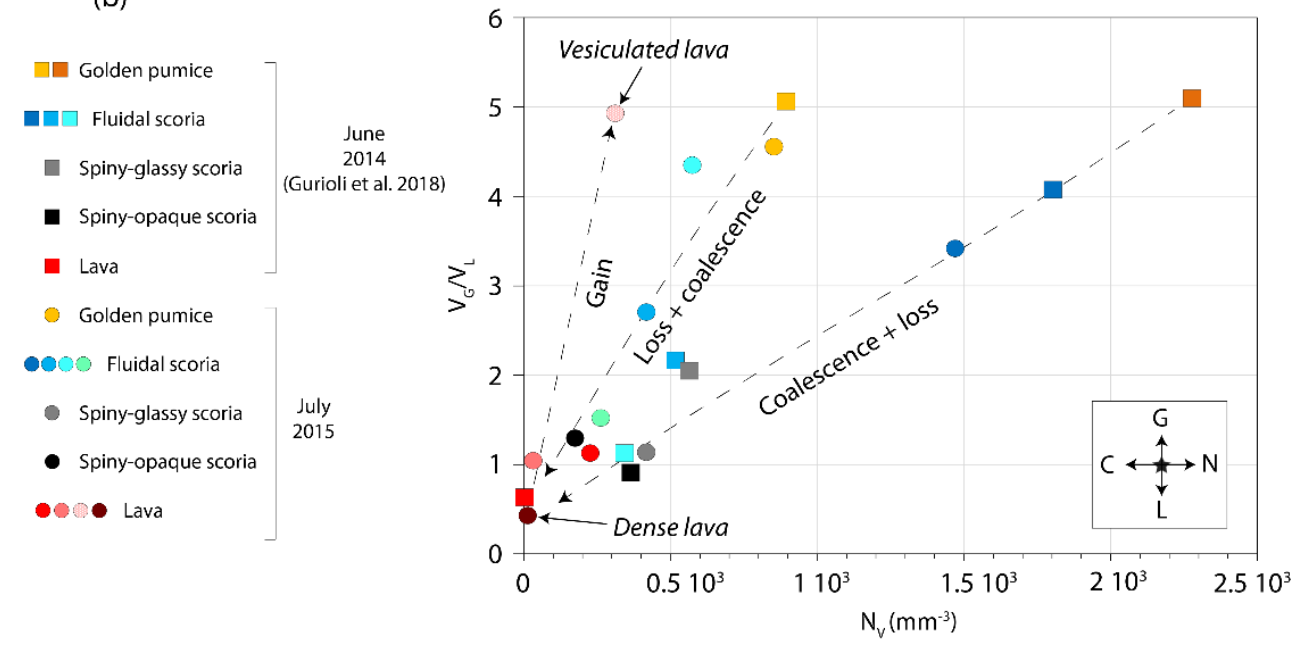

Fig. 6 - (a) Vesicle Size Distributions (VSD) of the June 2014 (Gurioli et al. 2018) and July 2015 selected samples. (b) Vesicle to melt ratio $\left(\mathrm{V}_{\mathrm{G}} / \mathrm{V}_{\mathrm{L}}\right)$ vs. vesicle density number $\left(\mathrm{N}_{\mathrm{V}}\right)$. The different trends reflecting different mechanisms are represented by the arrows: $\mathrm{N}$ for vesicle nucleation, $\mathrm{G}$ for vesicle growth, $\mathrm{C}$ for vesicle coalescence and $\mathrm{L}$ for vesicle loss. 


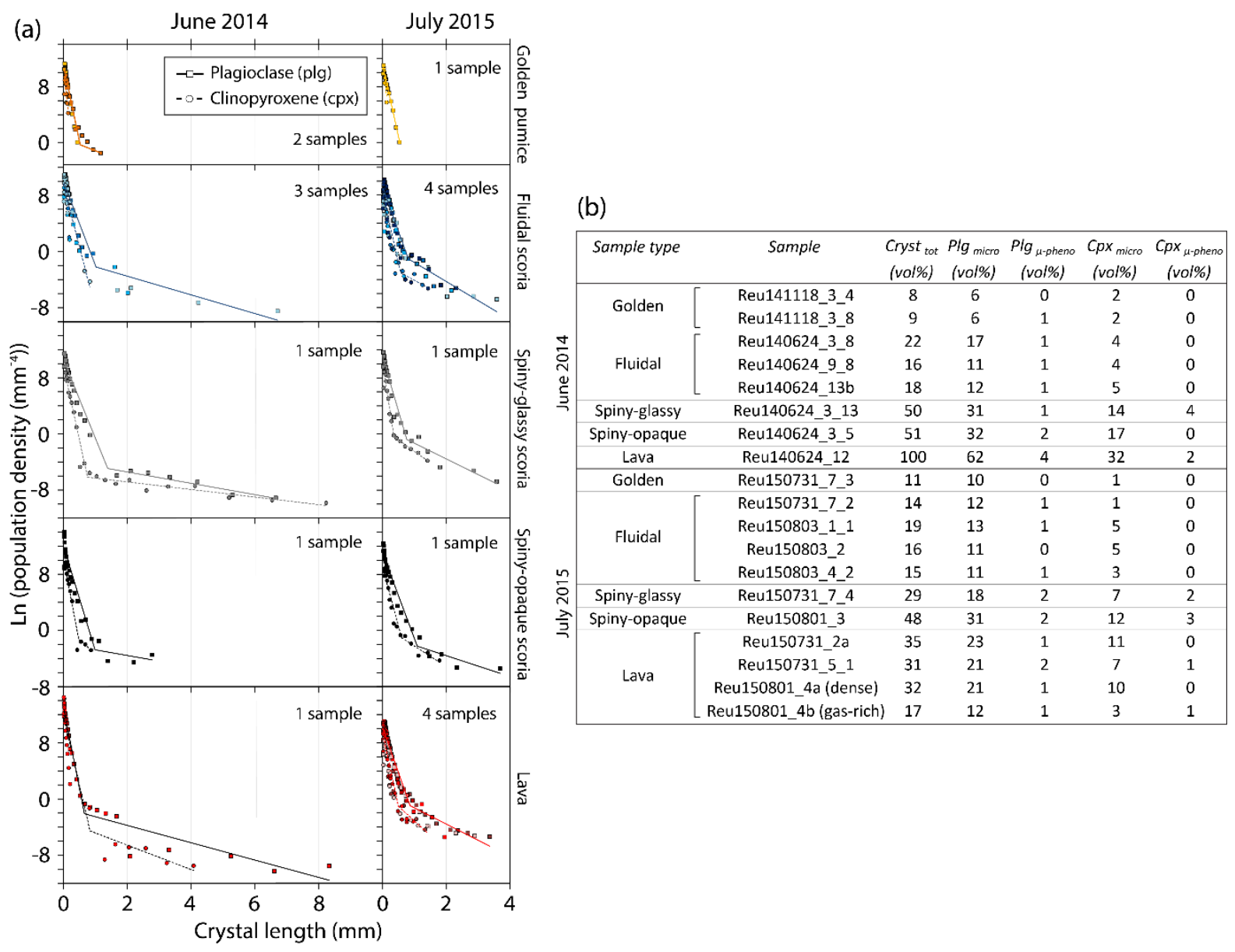

765 Fig. 7 - (a) Crystal Size Distributions (CSD) of the June 2014 and July 2015 selected samples. (b) Crystal content of the June 2014 and July 2015 selected samples. 

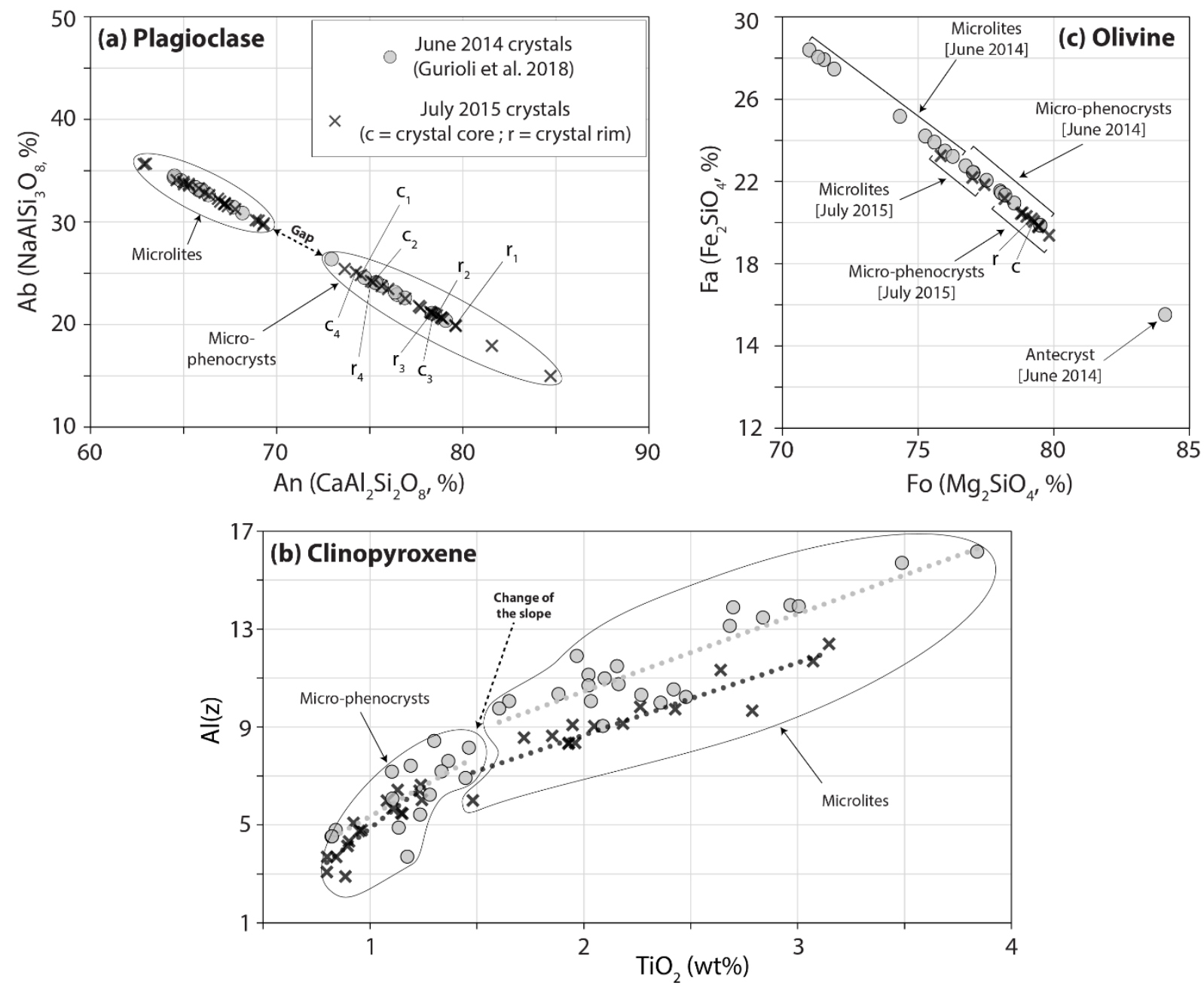

Fig. 8 - Crystal compositions of (a) plagioclases (albite vs. anorthite), (b) clinopyroxenes ( $\mathrm{Al}(\mathrm{z}) \mathrm{vs} . \mathrm{TiO}_{2}$ ) and (black crosses). Each $\mathrm{c}$ and $\mathrm{r}$ represent a couple of core and rim compositions on a same crystal. 


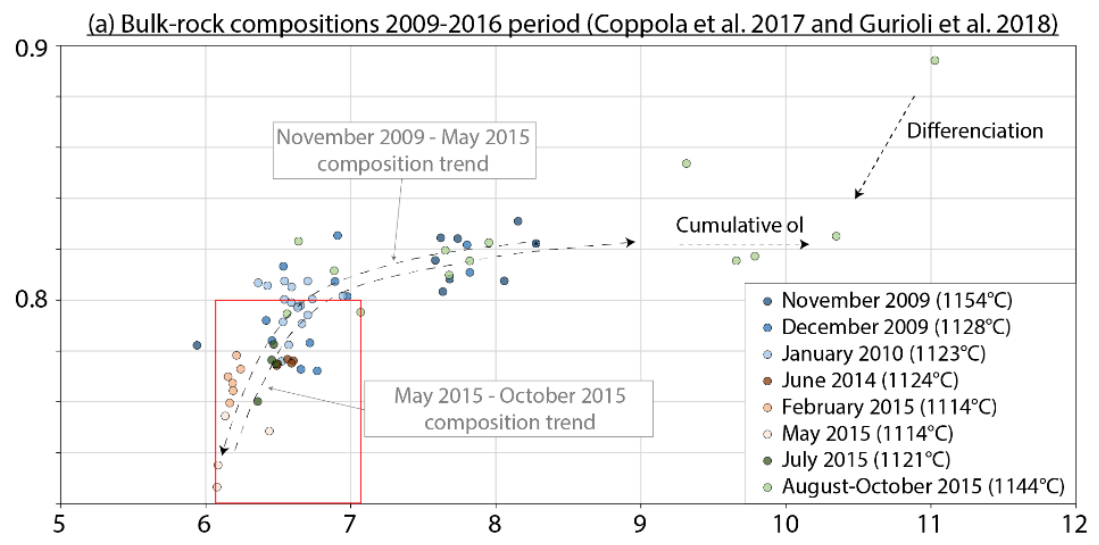

(b) Hydrous ( 500 bar) experimental compositions (Brugier 2016)
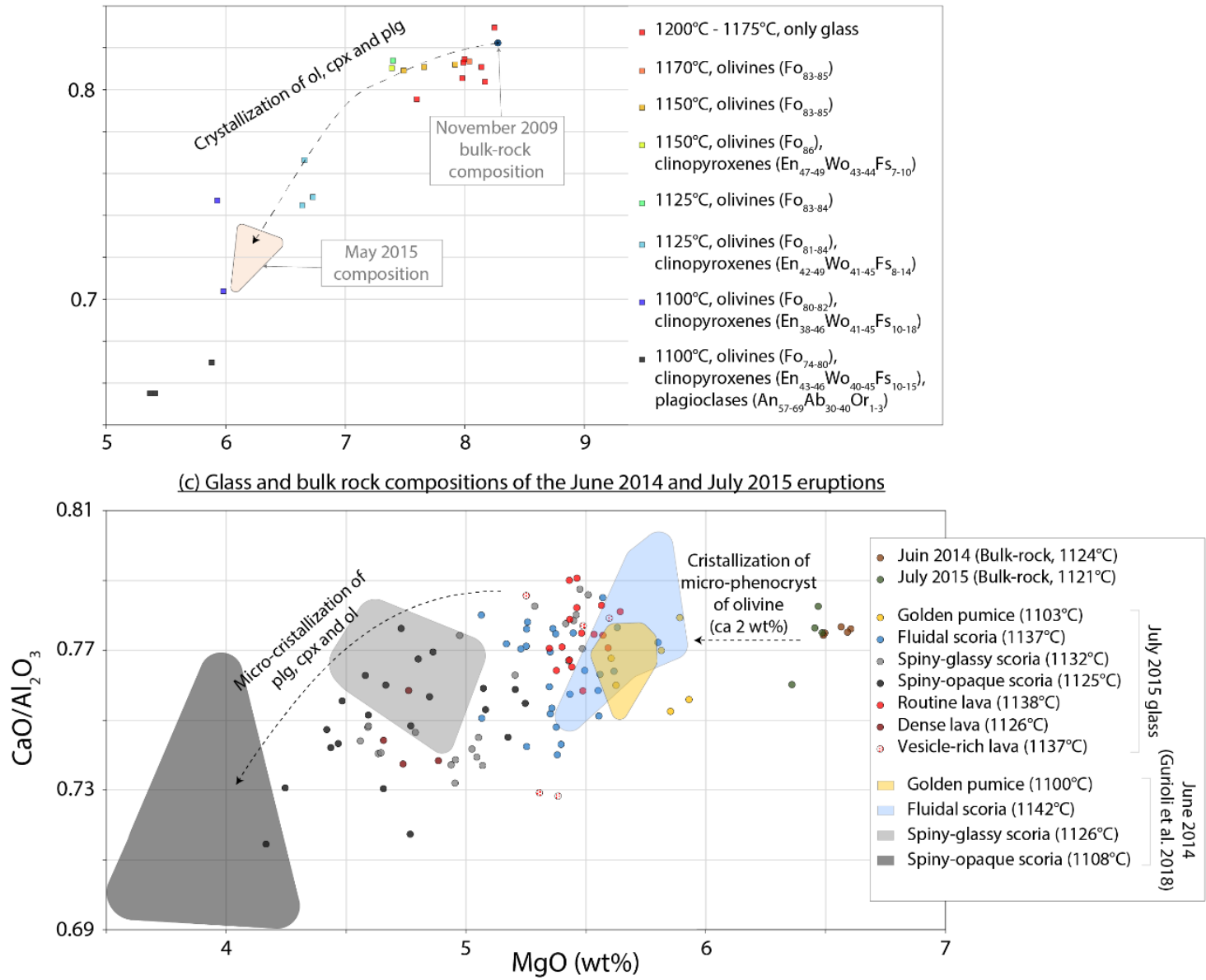

Fig. 9 - (a) Bulk rock compositions of the different eruptions that occurred between November 2009 and August-October $2015\left(\mathrm{CaO} / \mathrm{Al}_{2} \mathrm{O}_{3}\right.$ vs. $\left.\mathrm{MgO}\right)$. The red box represent the composition range of the typical aphyric transitional basalts of PdF. (b) Glass compositions $\left(\mathrm{CaO} / \mathrm{Al}_{2} \mathrm{O}_{3}\right.$ vs. $\left.\mathrm{MgO}\right)$ from hydrous experiments of Brugier (2016). Experiments were performed from the November 2009 melt composition and by progressively cooling from $1200^{\circ} \mathrm{C}$ until $1100^{\circ} \mathrm{C}$ with a constant pressure of $50 \mathrm{MPa}$ and controlled redox conditions. The experimental temperatures and the different present phases with their compositions are also reported. (c) Bulkrock and glass compositions $\left(\mathrm{CaO} / \mathrm{Al}_{2} \mathrm{O}_{3}\right.$ vs. $\left.\mathrm{MgO}\right)$ of the June 2014 (Gurioli et al. 2018) and July 2015 samples. 


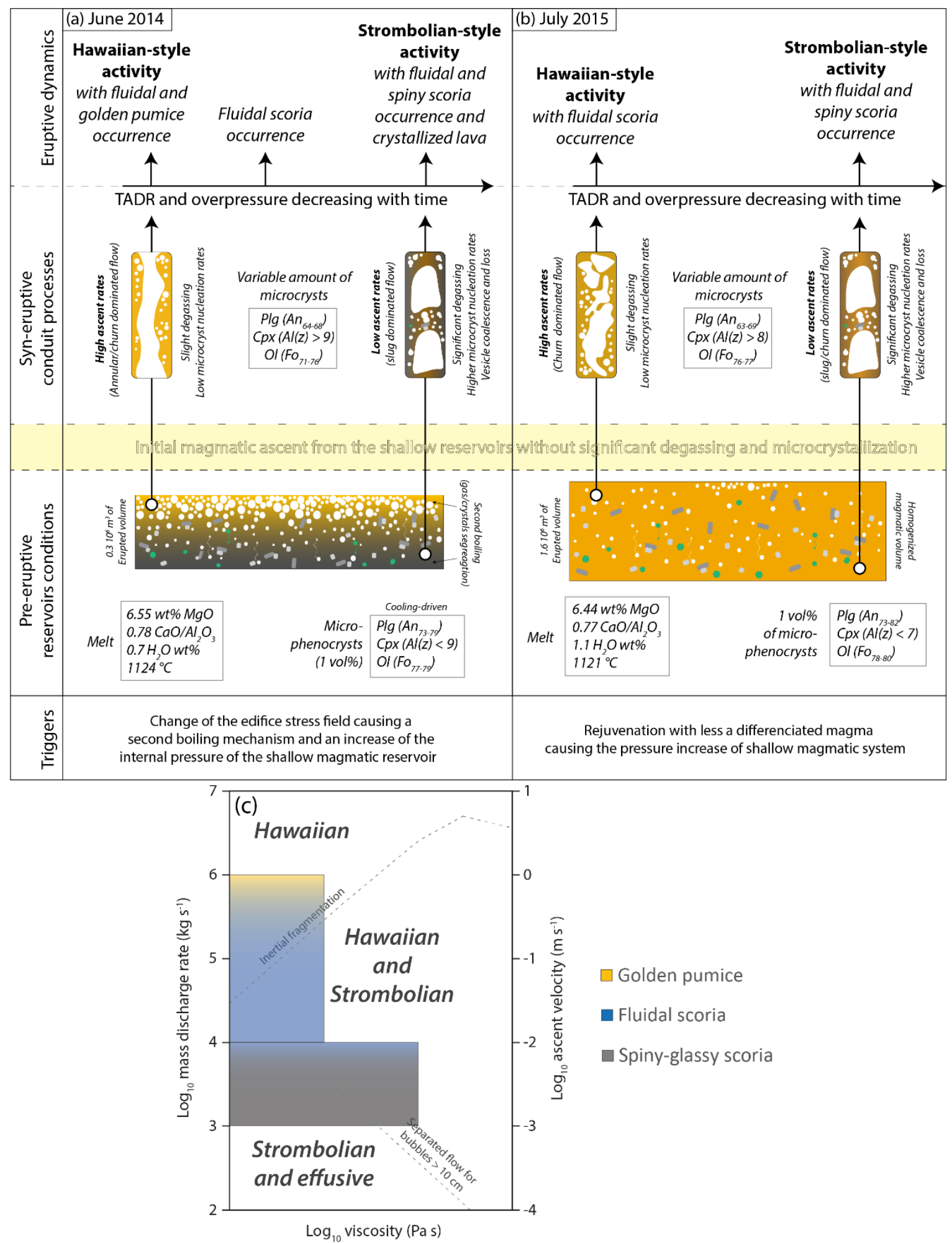

796 Fig. 10 - Comparison of the eruptive models of (a) the June 2014 and (b) the July 2015 eruptions. The shades of yellow represent a microlite-free matrix whereas the shades of grey represent a microlite-rich matrix. (c)

798 Eruptive dynamics with associated products integrated in the Gonnerman and Manga (2012) model, considering basaltic viscosities, magma mass discharge rates and ascent velocities. 
801

802

803

804

805

806

807

808

809

810

811

812

813

814

815

816

817

818

819

820

821

822

823

824

825

Aki, K., \& Ferrazzini, V. (2000). Seismic monitoring and modeling of an active volcano for prediction. Journal of Geophysical Research: Solid Earth, 105(B7), 16617-16640. https://doi.org/10.1029/2000JB900033

Aloisi, M., Mattia, M., Ferlito, C., Palano, M., Bruno, V., \& Cannavò, F. (2011). Imaging the multi-level magma reservoir at Mt. Etna volcano (Italy). Geophysical Research Letters, 38(16), n/a-n/a. https://doi.org/10.1029/2011GL048488

Anderson, A. T. (1995). $\mathrm{CO}_{2}$ and the eruptibility of picrite and komatiite. Lithos, 34(1-3), 19-25. https://doi.org/10.1016/0024-4937(95)90005-5

Andronico, D., \& Corsaro, R. A. (2011). Lava fountains during the episodic eruption of South-East Crater (Mt. Etna), 2000: insights into magma-gas dynamics within the shallow volcano plumbing system. Bulletin of Volcanology, 73(9), 1165-1178. https://doi.org/10.1007/s00445-011-0467-y

Applegarth, L. J., Tuffen, H., James, M. R., \& Pinkerton, H. (2013). Degassing-driven crystallisation in basalts. Earth-Science Reviews, 116(1), 1-16. https://doi.org/10.1016/j.earscirev.2012.10.007

Bachèlery, P. (1981). Le Piton de la Fournaise (île de la Réunion). Etude volcanologique, structurale et pétrologique.

Battaglia, J., Ferrazzini, V., Staudacher, T., Aki, K., \& Cheminée, J.-L. (2005). Pre-eruptive migration of earthquakes at the Piton de la Fournaise volcano (Réunion Island). Geophysical Journal International, 161(2), 549-558. https://doi.org/10.1111/j.1365-246X.2005.02606.x

Boivin, P., \& Bachèlery, P. (2009). Petrology of 1977 to 1998 eruptions of Piton de la Fournaise, La Réunion Island. Journal of Volcanology and Geothermal Research, 184(1-2), 109-125. https://doi.org/10.1016/j.jvolgeores.2009.01.012

Bonaccorso, A., Calvari, S., Currenti, G., Del Negro, C., Ganci, G., Linde, A., ... Sicali, A. (2013). From source to surface: dynamics of Etna's lava fountains investigated by continuous strain, magnetic, ground and satellite thermal data. Bulletin of Volcanology, 75(2), 690. https://doi.org/10.1007/s00445-013-0690-9

Brugier, Y.-A. (2016). Magmatologie du Piton de la Fournaise (Ile de la Réunion). Approche Volcanologique, Pétrologique et Expérimentale. 
Cashman, K. V. (1988). Crystallization of Mount St. Helens 1980-1986 dacite: A quantitative textural approach. Bulletin of Volcanology, 50(3), 194-209. https://doi.org/10.1007/BF01079682

Colombier, M., Wadsworth, F. B., Gurioli, L., Scheu, B., Kueppers, U., Di Muro, A., \& Dingwell, D. B. (2017). The evolution of pore connectivity in volcanic rocks. Earth and Planetary Science Letters, 462, 99-109. https://doi.org/10.1016/j.eps1.2017.01.011

Coppola, D., Laiolo, M., Cigolini, C., Donne, D. D., \& Ripepe, M. (2016). Enhanced volcanic hot-spot detection using MODIS IR data: results from the MIROVA system. Geological Society, London, Special Publications, 426(1), 181-205. https://doi.org/10.1144/SP426.5

Coppola, D., Di Muro, A., Peltier, A., Villeneuve, N., Ferrazzini, V., Favalli, M., ... Aiuppa, A. (2017). Shallow system rejuvenation and magma discharge trends at Piton de la Fournaise volcano (La Réunion Island). Earth and Planetary Science Letters, 463(463), 13-24. https://doi.org/10.1016/j.epsl.2017.01.024

Corsaro, R. A., \& Pompilio, M. (2004). Buoyancy-controlled eruption of magmas at Mt Etna. Terra Nova, 16(1), 16-22. https://doi.org/10.1046/j.1365-3121.2003.00520.x

Corsaro, R. A., Andronico, D., Behncke, B., Branca, S., Caltabiano, T., Ciancitto, F., ... Spata, G. (2017). Monitoring the December 2015 summit eruptions of Mt. Etna (Italy): Implications on eruptive dynamics. Journal of Volcanology and Geothermal Research, 341(December 2015), 53-69. https://doi.org/10.1016/j.jvolgeores.2017.04.018

Di Muro, A., Metrich, N., Vergani, D., Rosi, M., Armienti, P., Fougeroux, T., ... Civetta, L. (2014). The Shallow Plumbing System of Piton de la Fournaise Volcano (La Reunion Island, Indian Ocean) Revealed by the Major 2007 Caldera-Forming Eruption. Journal of Petrology, 55(7), 1287-1315. https://doi.org/10.1093/petrology/egu025

Di Muro, A., Staudacher, T., Ferrazzini, V., Métrich, N., Besson, P., Garofalo, C., \& Villemant, B. (2015). Shallow Magma Storage at Piton de la Fournaise Volcano After 2007 Summit Caldera Collapse Tracked in Pele’s Hairs. In American Geophysical Union Monograph (Vol. 208, pp. 189-212). https://doi.org/10.1002/9781118872079.ch9

Di Muro, A., Métrich, N., Allard, P., Aiuppa, A., Burton, M., Galle, B., \& Staudacher, T. (2016). Magma Degassing at Piton de la Fournaise Volcano. In Active Volcanoes of the Southwest Indian Ocean. Active 
Edmonds, M., Sides, I. R., Swanson, D. A., Werner, C., Martin, R. S., Mather, T. A., ... Elias, T. (2013). Magma storage, transport and degassing during the 2008-10 summit eruption at Kîlauea Volcano, Hawai ${ }^{\circ} \mathrm{i}$. Geochimica et Cosmochimica Acta, 123, 284-301. https://doi.org/10.1016/j.gca.2013.05.038

Edmonds, Marie, \& Wallace, P. J. (2017). Volatiles and Exsolved Vapor in Volcanic Systems. Elements, 13(1), 29-34. https://doi.org/10.2113/gselements.13.1.29

Edwards, M. J., Pioli, L., Andronico, D., Scollo, S., Ferrari, F., \& Cristaldi, A. (2018). Shallow factors controlling the explosivity of basaltic magmas: The 17-25 May 2016 eruption of Etna Volcano (Italy). Journal of Volcanology and Geothermal Research, 357, 425-436. https://doi.org/10.1016/j.jvolgeores.2018.05.015

Fisk, M. R., Upton, B. G. J., Ford, C. E., \& White, W. M. (1988). Geochemical and experimental study of the genesis of magmas of Reunion Island, Indian Ocean. Journal of Geophysical Research: Solid Earth, 93(B5), 4933-4950. https://doi.org/10.1029/JB093iB05p04933

Formenti, Y., \& Druitt, T. . (2003). Vesicle connectivity in pyroclasts and implications for the fluidisation of fountain-collapse pyroclastic flows, Montserrat (West Indies). Earth and Planetary Science Letters, 214(3-4), 561-574. https://doi.org/10.1016/S0012-821X(03)00386-8

Gardner, J. E., Thomas, R. M. E., Jaupart, C., \& Tait, S. (1996). Fragmentation of magma during Plinian volcanic eruptions. Bulletin of Volcanology, 58(2-3), 144-162. https://doi.org/10.1007/s004450050132

Gerlach, T. M. (1986). Exsolution of $\mathrm{H}_{2} \mathrm{O}, \mathrm{CO}_{2}$, and $\mathrm{S}$ during eruptive episodes at Kilauea Volcano, Hawaii. Journal of Geophysical Research: Solid Earth, 91(B12), 12177-12185. https://doi.org/10.1029/JB091iB12p12177

Giordano, D., \& Dingwell, D. (2003). Viscosity of hydrous Etna basalt: implications for Plinian-style basaltic eruptions. Bulletin of Volcanology, 65(1), 8-14. https://doi.org/10.1007/s00445-002-0233-2

Gonnermann, H. M., Manga, M. (2013). Dynamics of magma ascent in the volcanic conduit. In T. K. P. Gregg \& R. M. C. Lopes (Eds.), Modeling Volcanic Processes (Vol. 99, pp. 55-84). Cambridge: Cambridge University Press. https://doi.org/10.1017/CBO9781139021562.004 
Gurioli, L., Andronico, D., Bachelery, P., Balcone-Boissard, H., Battaglia, J., Boudon, G., ... Thordarson, T. (2015). MeMoVolc consensual document: a review of cross-disciplinary approaches to characterizing small explosive magmatic eruptions. Bulletin of Volcanology, 77(6), 49. https://doi.org/10.1007/s00445015-0935-x

Gurioli, L., Di Muro, A., Vlastélic, I., Moune, S., Thivet, S., et al. (2018). Integrating field, textural, and geochemical monitoring to track eruption triggers and dynamics: a case study from Piton de la Fournaise. Solid Earth, 9(2), 431-455. https://doi.org/10.5194/se-9-431-2018

Harris, A. J. L., Dehn, J., \& Calvari, S. (2007). Lava effusion rate definition and measurement: a review. Bulletin of Volcanology, 70(1), 1-22. https://doi.org/10.1007/s00445-007-0120-y

Harris, A. J. L., Villeneuve, N., Di Muro, A., Ferrazzini, V., Peltier, A., Coppola, D., ... Arellano, S. (2017). Effusive crises at Piton de la Fournaise 2014-2015: a review of a multi-national response model. Journal of Applied Volcanology, 6(1), 11. https://doi.org/10.1186/s13617-017-0062-9

Harris, A. J. L., Mannini, Thivet, S., Chevrel, M. O., Gurioli, L., Villeneuve, N., Di Muro, A., Peltier, A. (2019). How Shear Helps Lava to Flow. Geology, November. https://doi.org/10.1130/G47110.1.

Head, J. W., \& Wilson, L. (1987). Lava fountain heights at Pu'u 'O'o, Kilauea, Hawaii: Indicators of amount and variations of exsolved magma volatiles. Journal of Geophysical Research: Solid Earth, 92(B13), 13715-13719. https://doi.org/10.1029/JB092iB13p13715

Head, J. W., \& Wilson, L. (1989). Basaltic pyroclastic eruptions: Influence of gas-release patterns and volume fluxes on fountain structure, and the formation of cinder cones, spatter cones, rootless flows, lava ponds and lava flows. Journal of Volcanology and Geothermal Research, 37(3-4), 261-271. https://doi.org/10.1016/0377-0273(89)90083-8

Higgins, M. D. (2000). Measurement of crystal size distributions. American Mineralogist, 85(9), 1105-1116. https://doi.org/10.2138/am-2000-8-901

Higgins, M. D. (2006). Quantitative Textural Measurements in Igneous and Metamorphic Petrology. Cambridge: Cambridge University Press. https://doi.org/10.1017/CBO9780511535574

Holt, S. J., Carey, R. J., Houghton, B. F., Orr, T., McPhie, J., \& Feig, S. (2019). Eruption and fountaining dynamics of selected 1985-1986 high fountaining episodes at Kīlauea volcano, Hawai'i, from quantitative 

vesicle microtexture analysis. Journal of Volcanology and Geothermal Research, 369, 21-34. https://doi.org/10.1016/j.jvolgeores.2018.11.011

Houghton, B. F., \& Wilson, C. J. N. (1989). A vesicularity index for pyroclastic deposits. Bulletin of Volcanology, 51(6), 451-462. https://doi.org/10.1007/BF01078811

Houghton, B. F., Wilson, C. J. N., Del Carlo, P., Coltelli, M., Sable, J. E., \& Carey, R. (2004). The influence of conduit processes on changes in style of basaltic Plinian eruptions: Tarawera 1886 and Etna 122 BC. Journal of Volcanology and Geothermal Research, 137(1-3), 1-14. https://doi.org/10.1016/j.jvolgeores.2004.05.009

Houghton, B. F., \& Gonnermann, H. M. (2008). Basaltic explosive volcanism: Constraints from deposits and models. Geochemistry, 68(2), 117-140. https://doi.org/10.1016/j.chemer.2008.04.002

Houghton, B. F., Taddeucci, J., Andronico, D., Gonnermann, H. M., Pistolesi, M., Patrick, M. R., ... Scarlato, P. (2016). Stronger or longer: Discriminating between Hawaiian and Strombolian eruption styles. Geology, 44(2), 163-166. https://doi.org/10.1130/G37423.1

Jaupart, C., \& Vergniolle, S. (1988). Laboratory models of Hawaiian and Strombolian eruptions. Nature, 331(6151), 58-60. https://doi.org/10.1038/331058a0

Jaupart, C., \& Vergniolle, S. (1989). The generation and collapse of a foam layer at the roof of a basaltic magma chamber. Journal of Fluid Mechanics, 203(347), 347. https://doi.org/10.1017/S0022112089001497

Kawabata, E., Cronin, S. J., Bebbington, M. S., Moufti, M. R. H., El-Masry, N., \& Wang, T. (2015). Identifying multiple eruption phases from a compound tephra blanket: an example of the AD1256 Al-Madinah eruption, Saudi Arabia. Bulletin of Volcanology, 77(1), 6. https://doi.org/10.1007/s00445-014-0890-y

Kolzenburg, S., Giordano, D., Giordano, D., Di Muro, A., Di Muro, A., Dingwell, D., \& Dingwell, D. (2018). Equilibrium Viscosity and Disequilibrium Rheology of a high Magnesium Basalt from Piton De La Fournaise volcano, La Reunion, Indian Ocean, France. Annals of Geophysics, 61(Vol 61 (2018)). https://doi.org/10.4401/ag-7839

Kuo, L. C., \& Kirkpatrick, R. J. (1982). Pre-eruption history of phyric basalts from DSDP legs 45 and 46 : Evidence from morphology and zoning patterns in plagioclase. Contributions to Mineralogy and Petrology, 79(1), 13-27. https://doi.org/10.1007/BF00376957 
La Spina, G., Burton, M., \& de’ Michieli Vitturi, M. (2015). Temperature evolution during magma ascent in basaltic effusive eruptions: A numerical application to Stromboli volcano. Earth and Planetary Science Letters, 426, 89-100. https://doi.org/10.1016/j.epsl.2015.06.015

Lange, R. A., Frey, H. M., \& Hector, J. (2009). A thermodynamic model for the plagioclase-liquid hygrometer/thermometer. American Mineralogist, 94(4), 494-506. https://doi.org/10.2138/am.2009.3011

Lesne, Priscille, Bruno Scaillet, Michel Pichavant, and Jean-Michel Beny. 2011. "The Carbon Dioxide Solubility in Alkali Basalts: An Experimental Study.” Contributions to Mineralogy and Petrology 162 (1): 153-68. https://doi.org/10.1007/s00410-010-0585-0.

Lengliné, O., Duputel, Z., \& Ferrazzini, V. (2016). Uncovering the hidden signature of a magmatic recharge at Piton de la Fournaise volcano using small earthquakes. Geophysical Research Letters, 43(9), 4255-4262. https://doi.org/10.1002/2016GL068383

Lindoo, A., Larsen, J. F., Cashman, K. V., Dunn, A. L., \& Neill, O. K. (2016). An experimental study of permeability development as a function of crystal-free melt viscosity. Earth and Planetary Science Letters, 435, 45-54. https://doi.org/10.1016/j.eps1.2015.11.035

Lindoo, A., Larsen, J. F., Cashman, K. V., \& Oppenheimer, J. (2017). Crystal controls on permeability development and degassing in basaltic andesite magma. Geology, 45(9), 831-834. https://doi.org/10.1130/G39157.1

Mangan, M. T., \& Cashman, K. V. (1996). The structure of basaltic scoria and reticulite and inferences for vesiculation, foam formation, and fragmentation in lava fountains. Journal of Volcanology and Geothermal Research, 73(1-2), 1-18. https://doi.org/10.1016/0377-0273(96)00018-2

Marsh, B. D. (1988). Crystal size distribution (CSD) in rocks and the kinetics and dynamics of crystallization. Contributions to Mineralogy and Petrology, 99(3), 277-291. https://doi.org/10.1007/BF00375362

Métrich, N., \& Rutherford, M. J. (1998). Low Pressure Crystallization Paths of H2O-Saturated BasalticHawaiitic Melts from Mt Etna: Implications for Open-System Degassing of Basaltic Volcanoes. Geochimica et Cosmochimica Acta, 62(7), 1195-1205. https://doi.org/10.1016/S0016-7037(98)00048-9

Michon, L., Ferrazzini, V., Di Muro, A., Villeneuve, N., \& Famin, V. (2015). Rift zones and magma plumbing system of Piton de la Fournaise volcano: How do they differ from Hawaii and Etna? Journal of 
961

Moitra, P., Gonnermann, H. M., Houghton, B. F., \& Giachetti, T. (2013). Relating vesicle shapes in pyroclasts to eruption styles. Bulletin of Volcanology, 75(2), 691. https://doi.org/10.1007/s00445-013-0691-8

Moitra, P., Gonnermann, H. M., Houghton, B. F., \& Tiwary, C. S. (2018). Fragmentation and Plinian eruption of crystallizing basaltic magma. Earth and Planetary Science Letters, 500, 97-104. https://doi.org/10.1016/j.epsl.2018.08.003

Mollo, S., Giacomoni, P. P., Coltorti, M., Ferlito, C., Iezzi, G., \& Scarlato, P. (2015). Reconstruction of magmatic variables governing recent Etnean eruptions: Constraints from mineral chemistry and $\mathrm{P}-\mathrm{T}-\mathrm{fO} 2-$ H2O modeling. Lithos, 212-215, 311-320. https://doi.org/10.1016/j.lithos.2014.11.020

Morandi, A., Di Muro, A., Principe, C., Michon, L., Leroi, G., Norelli, F., \& Bachèlery, P. (2016). Pre-historic ( $<5$ kiloyear) Explosive Activity at Piton de la Fournaise Volcano. In Active Volcanoes of the Southwest Indian Ocean. Active Volcanoes of the World. (pp. 107-138). https://doi.org/10.1007/978-3-642-31395$0 \_8$

Morgan, D. J., \& Jerram, D. A. (2006). On estimating crystal shape for crystal size distribution analysis. Journal of Volcanology and Geothermal Research, 154(1-2), 1-7. https://doi.org/10.1016/j.jvolgeores.2005.09.016

Ort, M. H., Di Muro, A., Michon, L., \& Bachèlery, P. (2016). Explosive eruptions from the interaction of magmatic and hydrothermal systems during flank extension: the Bellecombe Tephra of Piton de La Fournaise (La Réunion Island). Bulletin of Volcanology, 78(1), 5. https://doi.org/10.1007/s00445-0150998-8

Parcheta, C. E., Houghton, B. F., \& Swanson, D. A. (2013). Contrasting patterns of vesiculation in low, intermediate, and high Hawaiian fountains: A case study of the 1969 Mauna Ulu eruption. Journal of Volcanology and Geothermal Research, 255, 79-89. https://doi.org/10.1016/j.jvolgeores.2013.01.016

Parfitt, E. A., \& Wilson, L. (1995). Explosive volcanic eruptions-IX. The transition between Hawaiian-style lava fountaining and Strombolian explosive activity. Geophysical Journal International, 121(1), 226-232. https://doi.org/10.1111/j.1365-246X.1995.tb03523.x

Parfitt, E. A. (2004). A discussion of the mechanisms of explosive basaltic eruptions. Journal of Volcanology and Geothermal Research, 134(1-2), 77-107. https://doi.org/10.1016/j.jvolgeores.2004.01.002 
Patanè, D., Di Grazia, G., Cannata, A., Montalto, P., \& Boschi, E. (2008). Shallow magma pathway geometry at Mt. Etna volcano. Geochemistry, Geophysics, Geosystems, 9(12), n/a-n/a. https://doi.org/10.1029/2008GC002131

Peltier, A., Ferrazzini, V., Staudacher, T., \& Bachèlery, P. (2005). Imaging the dynamics of dyke propagation prior to the 2000-2003 flank eruptions at Piton de La Fournaise, Reunion Island. Geophysical Research Letters, 32(22), n/a-n/a. https://doi.org/10.1029/2005GL023720

Peltier, A., Famin, V., Bachèlery, P., Cayol, V., Fukushima, Y., \& Staudacher, T. (2008). Cyclic magma storages and transfers at Piton de La Fournaise volcano (La Réunion hotspot) inferred from deformation and geochemical data. Earth and Planetary Science Letters, 270(3-4), 180-188. https://doi.org/10.1016/j.eps1.2008.02.042

Peltier, A., Poland, M. P., \& Staudacher, T. (2015). Are Piton de la Fournaise (La Réunion) and Kīlauea (Hawai‘i) Really “Analog Volcanoes”? In Hawaiian Volcanoes (pp. 507-531). https://doi.org/10.1002/9781118872079.ch23

Peltier, A., Beauducel, F., Villeneuve, N., Ferrazzini, V., Di Muro, A., Aiuppa, A., ... Taisne, B. (2016). Deep fluid transfer evidenced by surface deformation during the 2014-2015 unrest at Piton de la Fournaise volcano. Journal of Volcanology and Geothermal Research, 321, 140-148. https://doi.org/10.1016/j.jvolgeores.2016.04.031

Pering, T. D., McGonigle, A. J. S., James, M. R., Capponi, A., Lane, S. J., Tamburello, G., \& Aiuppa, A. (2017). The dynamics of slug trains in volcanic conduits: Evidence for expansion driven slug coalescence. Journal of Volcanology and Geothermal Research, 348, 26-35. https://doi.org/10.1016/j.jvolgeores.2017.10.009

Pichavant, M., Brugier, Y., \& Di Muro, A. (2016). Petrological and Experimental Constraints on the Evolution of Piton de la Fournaise Magmas. In Active Volcanoes of the Southwest Indian Ocean. Active Volcanoes of the World. (pp. 171-184). https://doi.org/10.1007/978-3-642-31395-0_10

Pioli, L., Bonadonna, C., Azzopardi, B. J., Phillips, J. C., \& Ripepe, M. (2012). Experimental constraints on the outgassing dynamics of basaltic magmas. Journal of Geophysical Research: Solid Earth, 117(B3). https://doi.org/10.1029/2011JB008392

Pioli, L., Pistolesi, M., \& Rosi, M. (2014). Transient explosions at open-vent volcanoes: The case of Stromboli (Italy). Geology, 42(10), 863-866. https://doi.org/10.1130/G35844.1 
Pioli, L., Azzopardi, B. J., Bonadonna, C., Brunet, M., \& Kurokawa, A. K. (2017). Outgassing and eruption of basaltic magmas: The effect of conduit geometry. Geology, 45(8), G38787.1. https://doi.org/10.1130/G38787.1

Polacci, M., Corsaro, R. A., \& Andronico, D. (2006). Coupled textural and compositional characterization of basaltic scoria: Insights into the transition from Strombolian to fire fountain activity at Mount Etna, Italy. Geology, 34(3), 201. https://doi.org/10.1130/G22318.1

Polacci, M., Baker, D. R., La Rue, A., Mancini, L., \& Allard, P. (2012). Degassing behaviour of vesiculated basaltic magmas: an example from Ambrym volcano, Vanuatu Arc. Journal of Volcanology and Geothermal Research, 233-234, 55-64. https://doi.org/10.1016/j.jvolgeores.2012.04.019

Polacci, M., Andronico, D., de’ Michieli Vitturi, M., Taddeucci, J., \& Cristaldi, A. (2019). Mechanisms of Ash Generation at Basaltic Volcanoes: The Case of Mount Etna, Italy. Frontiers in Earth Science, 7(August). https://doi.org/10.3389/feart.2019.00193

Pompilio, M., Bertagnini, A., Del Carlo, P., \& Di Roberto, A. (2017). Magma dynamics within a basaltic conduit revealed by textural and compositional features of erupted ash: the December 2015 Mt. Etna paroxysms. Scientific Reports, 7(1), 4805. https://doi.org/10.1038/s41598-017-05065-x

Prôno, E., Battaglia, J., Monteiller, V., Got, J.-L., \& Ferrazzini, V. (2009). P-wave velocity structure of Piton de la Fournaise volcano deduced from seismic data recorded between 1996 and 1999. Journal of Volcanology and Geothermal Research, 184(1-2), 49-62. https://doi.org/10.1016/j.jvolgeores.2008.12.009

Putirka, K. D. (2008). Thermometers and Barometers for Volcanic Systems. Reviews in Mineralogy and Geochemistry, 69(1), 61-120. https://doi.org/10.2138/rmg.2008.69.3

Rae, A. S. P., Edmonds, M., Maclennan, J., Morgan, D., Houghton, B., Hartley, M. E., \& Sides, I. (2016). Time scales of magma transport and mixing at Kīlauea Volcano, Hawai’i. Geology, 44(6), 463-466. https://doi.org/10.1130/G37800.1

Rhéty, M., Harris, A., Villeneuve, N., Gurioli, L., Médard, E., Chevrel, O., \& Bachélery, P. (2017). A comparison of cooling-limited and volume-limited flow systems: Examples from channels in the Piton de la Fournaise April 2007 lava-flow field. Geochemistry, Geophysics, Geosystems, 18(9), 3270-3291. https://doi.org/10.1002/2017GC006839 
Roeder, P. L., \& Emslie, R. F. (1970). Olivine-liquid equilibrium. Contributions to Mineralogy and Petrology, 29(4), 275-289. https://doi.org/10.1007/BF00371276

Roeder, P., Gofton, E., \& Thornber, C. (2006). Cotectic Proportions of Olivine and Spinel in Olivine-Tholeiitic Basalt and Evaluation of Pre-Eruptive Processes. Journal of Petrology, 47(5), 883-900. https://doi.org/10.1093/petrology/egi099

Roult, G., Peltier, A., Taisne, B., Staudacher, T., Ferrazzini, V., \& Di Muro, A. (2012). A new comprehensive classification of the Piton de la Fournaise activity spanning the 1985-2010 period. Search and analysis of short-term precursors from a broad-band seismological station. Journal of Volcanology and Geothermal Research, 241-242, 78-104. https://doi.org/10.1016/j.jvolgeores.2012.06.012

Sable, J. E., Houghton, B. F., Del Carlo, P., \& Coltelli, M. (2006). Changing conditions of magma ascent and fragmentation during the Etna 122 BC basaltic Plinian eruption: Evidence from clast microtextures. Journal of Volcanology and Geothermal Research, 158(3-4), 333-354. https://doi.org/10.1016/j.jvolgeores.2006.07.006

Shea, T., Houghton, B. F., Gurioli, L., Cashman, K. V., Hammer, J. E., \& Hobden, B. J. (2010). Textural studies of vesicles in volcanic rocks: An integrated methodology. Journal of Volcanology and Geothermal Research, 190(3-4), 271-289. https://doi.org/10.1016/j.jvolgeores.2009.12.003

Shea, T. (2017). Bubble nucleation in magmas: A dominantly heterogeneous process? Journal of Volcanology and Geothermal Research, 343, 155-170. https://doi.org/10.1016/j.jvolgeores.2017.06.025

Sparks, R. S. J. (1978). The dynamics of bubble formation and growth in magmas: A review and analysis. Journal of Volcanology and Geothermal Research, 3(1-2), 1-37. https://doi.org/10.1016/03770273(78)90002-1

Sparks, R. S. J., \& Huppert, H. E. (1984). Density changes during the fractional crystallization of basaltic magmas: fluid dynamic implications. Contributions to Mineralogy and Petrology, 85(3), 300-309. https://doi.org/10.1007/BF00378108

Staudacher, T., Ferrazzini, V., Peltier, A., Kowalski, P., Boissier, P., Catherine, P., ... Massin, F. (2009). The April 2007 eruption and the Dolomieu crater collapse, two major events at Piton de la Fournaise (La Réunion Island, Indian Ocean). Journal of Volcanology and Geothermal Research, 184(1-2), 126-137. 
Staudacher, T., Peltier, A., Ferrazzini, V., Di Muro, A., Boissier, P., Catherine, P., ... Lebreton, J. (2016). Fifteen Years of Intense Eruptive Activity (1998-2013) at Piton de la Fournaise Volcano: A Review. In Active Volcanoes of the Southwest Indian Ocean. Active Volcanoes of the World. (pp. 139-170).

Stovall, W. K., Houghton, B. F., Gonnermann, H., Fagents, S. A., \& Swanson, D. A. (2011). Eruption dynamics of Hawaiian-style fountains: the case study of episode 1 of the Kîlauea Iki 1959 eruption. Bulletin of

Stovall, W. K., Houghton, B. F., Hammer, J. E., Fagents, S. A., \& Swanson, D. A. (2012). Vesiculation of high fountaining Hawaiian eruptions: episodes 15 and 16 of 1959 Kīlauea Iki. Bulletin of Volcanology, 74(2),

Tait, S., Jaupart, C., \& Vergniolle, S. (1989). Pressure, gas content and eruption periodicity of a shallow, crystallising magma chamber. Earth and Planetary Science Letters, 92(1), 107-123.

Toramaru, A. (2006). BND (bubble number density) decompression rate meter for explosive volcanic eruptions.

Toramaru, A., Noguchi, S., Oyoshihara, S., \& Tsune, A. (2008). MND(microlite number density) water

Vergniolle, S., \& Jaupart, C. (1990). Dynamics of degassing at Kilauea Volcano, Hawaii. Journal of Geophysical Research, 95(B3), 2793. https://doi.org/10.1029/JB095iB03p02793 basaltic magmas at Kilauea Volcano. Bulletin of Volcanology, 59(5), 327-344. 
1097 White, J. D. L., \& Houghton, B. F. (2006). Primary volcaniclastic rocks. Geology, 34(8), 677. https://doi.org/10.1130/G22346.1 